\title{
注射用ニューキノロン系抗菌薬メシル酸パズフロキサシンの特長と 臨床的位置付け
}

南 新三郎, 服部 力三, 松田 朗

要約 : メシル酸パズフロキサシン $(\mathrm{PZFX}$ : パシル点滴静 注液 , パズクロス注) は富山化学工業株式会社において創 製され，三菱ウェルファーマ株式会社と富山化学工業株式 会社で共同開発された，1-aminocyclopropyl 基を有する 新規な注射用ニューキノロン系抗菌薬である．PZFXは静 注投与後に高い血中濃度を示しながらも，けいれん誘発作 用，局所刺激作用および血圧降下作用などの注射用二ュー キノロン系抗菌薬で懸念される作用か溺いことが基礎的検 討で認められている.一方，PZFX はセフェム系，カルバ ペネム系，アミノグリコシド系抗菌薬に耐性を示す細菌に 対しても強い抗菌力を示し, 兴の強い殺菌作用により各種 而性菌での動物感染実験モデルにおいて，既存注射用セフ エム系抗菌薬より優れた治療効果を示した . 更に, 臨床試 験においても，PZFX は注射用抗菌薬の対象となる中等症 以上の感染症にて，注射用セフェム系抗菌薬 ceftazidime (CAZ) と同等の臨床効果と安全性を示し, 加えて各科領 域の前投薬無効例に対しても良好な臨床効果を示した . こ れらの基礎試験および臨床試験成績から，PZFX は細菌感 染症治療の有用な選択肢として期待される. 本総説では, PZFX の基礎的・臨床的成績を概説し，注射用抗菌薬の中 における PZFX の臨床的位置付けについて考察する .

\section{1.はじめに}

ニューキノロン系抗菌薬は細菌特有の DNA topoisomerase に作用してDNAの複製を停止させることで, グラ 么陽性菌およびグラム陰性菌に対し，強い抗菌活性と幅広 い抗菌スペクトルを示す．また，作用機序の違いにより， 感染症治療において汎用されている $\beta$-ラクタム系抗菌薬

キーワード : メシル酸パズフロキサシン

注射用ニューキノロン系抗菌薬，耐性菌， DNA ジャイレース, トポイソメレース

富山化学工業株式会社 綜合研究所, 臨床開発部, 薬事室 ( ₹ 160-0023 東京都新宿区西新宿 3-2-5)

原稿受領日 : 2003 年 4 月 30 日, 編集委員会依頼総説
などの既存抗菌薬と交叉耐性を示さず，濃度依存性の強い 殺菌作用を有し, 更に, 各種細菌に対して postantibiotic effect (PAE) を示すことから，血中における薬剂濃度が MIC 以下になった後も細菌の再増殖を阻止する効果が期 待される．また，組織細胞内への移行は良好で，血中濃度 に比して組織内濃度が高く，細胞内寄生性微生物感染への 有効性を示すなどの特長も有する．

注射用ニューキノロン系抗菌薬は欧米を中心に開発され， 呼吸器, 尿路, 皮膚軟部組織, 腹腔内感染症, 骨・関節感 染症などに適応を有する ciprofloxacin(CPFX)，ofloxacin (OFLX) , levofloxacin (LVFX) などが相次いで承認され ている．欧米においては，これらニューキノロン系抗菌薬 の静注投与は, 経口投与時と同樣の血中濃度を示すように 用法用量か設定され，経口投与不能な病態あるいは重症感 染時又は急性期の病態を離脱するための治療剂として位置 付けられている(12)．また，二ューキノロン系抗菌薬は 他系統抗菌薬と耐性が交叉しにくく，他剂耐性菌による無 効例に対する臨床的有用性も確認されている(3)．なお， 本邦で最初に開発された注射用ニューキノロン系抗菌薬の CPFX 注も基本的には欧米と同樣なコンセプトで臨床導入 されたものと考えられるが，本邦における注射用ニューキ ノロン系抗菌薬に対する期待は欧米とは若干異なり，中等 症以上および難治性感染症に対して高い臨床効果を発揮す ることにあると思われる.しかし，効果の増強を意図して， 既存のニューキノロン系抗菌薬を注射剂とし，投与量を増 加させて血中濃度を高めることは，けいれん誘発作用を含 む中枢神経系作用，局所刺激性，血管炎(4,5) およびショ ック樣症状などのニューキノロン系抗菌薬でみられる副作 用が懸念される(6).このような状況において，PZFX は 「静脈内投与後に速やかに高い血中濃度が得られ，しかも 血中濃度を高めても中枢神経系などへの影響が少なく，従 来のニューキノロン系抗菌薬より安全域の拡大した新しい タイプのニューキノロン系抗菌薬」を目標に開発された薬 剂である。 
<smiles>C[C@H]1COc2c(C3(N)CC3)c(F)cc3c(=O)c(C(=O)O)cn1c23</smiles>

Fig. 1 Chemical structure of pazufloxacin mesilate (PZFX)

PZFX はキノロン骨格の 7 位側鎖に, 従来のニューキノ ロン系抗菌薬には見られなかった C - C (炭素 - 炭素結合) を介した新規な1-aminocyclopropyl 基を導入したことで (図 1)，静脈内投与後に高い血中濃度を示しながらも，け いれん誘発作用が弱く， $\beta$-ラクタム系抗菌薬などの既存 の注射用抗菌薬而性菌に対しても強い抗菌力を示し, 各種 細菌による動物感染実験モデルに対しても注射投与で良好
な治療効果を示した . また，これらのPZFXの有効性と 安全性に関する基礎的特長は開発時の臨床試験においても 確認されている.

以下にPZFXの発見の経緯, 主な薬理試験成績および 臨床試験成績について示し, 本薬の臨床的位置付けについ て考察する.なお，本総説に記載したデータは特に断りが ない限りPZFXの開発時に集積されたものである .

\section{2. 発見の経緯}

PZFX の発見は, キノロン系抗菌薬のプロトタイプであ る nalidixic acid (NA) が, ニューキノロン系抗菌薬と比 較して, 単回経口投与における血中濃度が高いこと(7) 並 びにマウス脳室内投与によるけいれん誘発作用(8) および GABA 受容体結合阻害作用(9) が弱い事実に着目したこ とが契機となった . 化学構造から NA と既存のニューキ ノロン系抗菌薬との相違点を比べると，NAの７位におけ る側鎖との結合樣式は $\mathrm{C}-\mathrm{CH}_{3}$ (炭素 - 炭素結合) であり， 既存のニューキノロン系抗菌薬では $\mathrm{C}-\mathrm{N}$ (炭素-室素結 合）である (図 2) . マウスを用いてキノロン系化合物の 中枢への作用を検討したところ，7 位結合が $\mathrm{C}-\mathrm{N}$ の場合<smiles>[Y]c1[X]c2c(cc1F)c(=O)c(C(=O)O)cn2[R]</smiles>

Quinolone antibiotic

Fig. 2 Chemical structure of nalidixic acid and other quinolone antibiotics

Table 1 Induction of convulsions after intracerebral injection of quinolone compounds in mice

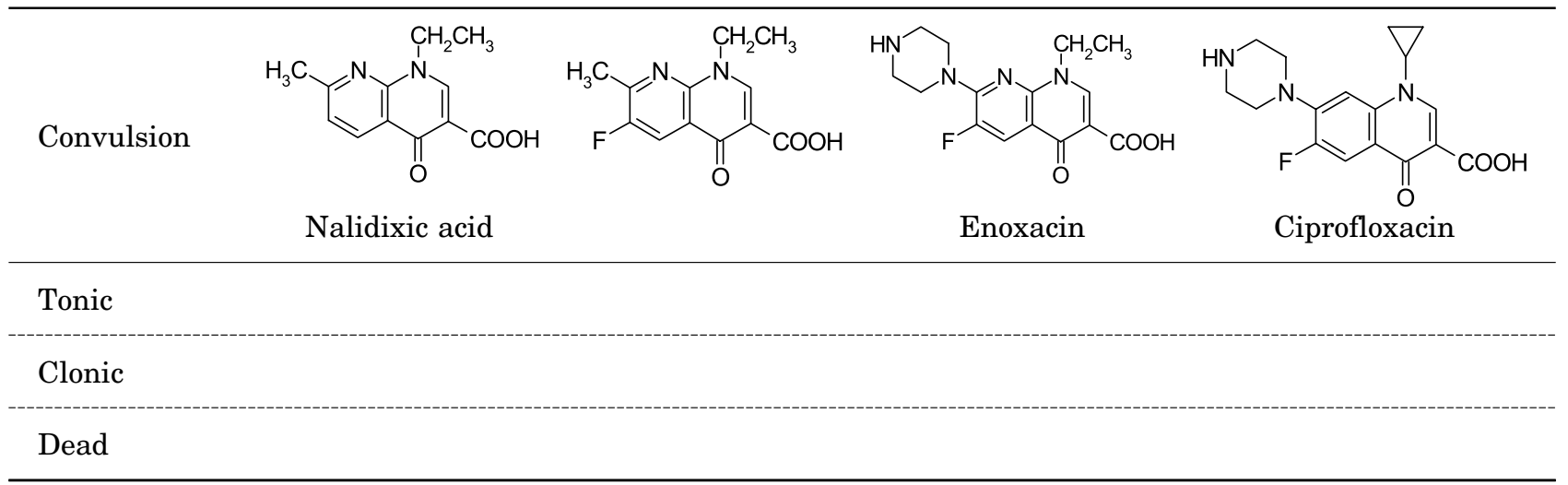

Positive/test animals, Dose: $50 \mu \mathrm{g} /$ mouse 


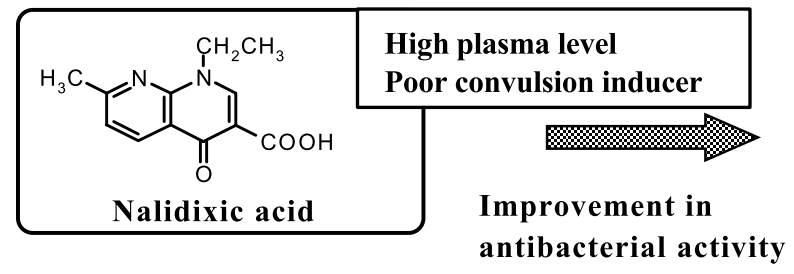

antibacterial activity

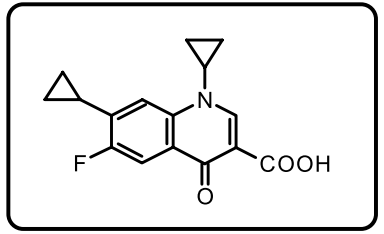

(1)

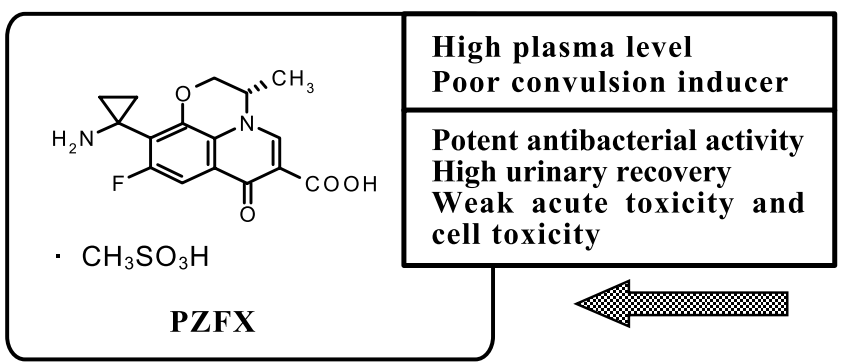

Optimization
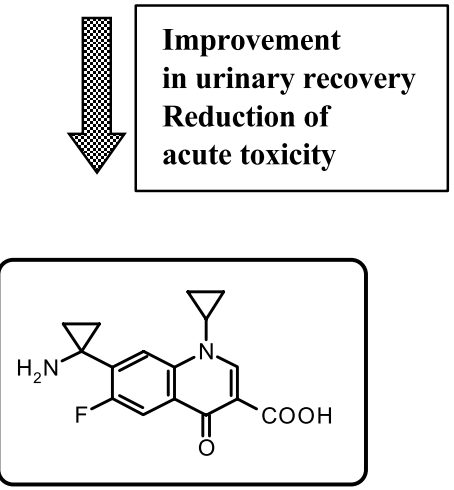

(2)

Fig. 3 Flow chart of chemical modification

にけいれん誘発作用が強く認められ， C-C 結合では弱か つた (表1).

そこで，7位側鎖の結合樣式と中枢神経系に対する作用 の関係に着目し，側鎖の検討を行い，抗菌活性か強く，静 注投与で高い血中濃度を示し，更に急性毒性やけいれん誘 発作用などの毒性か溺い化合物の探索を行った . 探索の流 れを図 3 に示す。

NA 母核のナフチリジンをキノリンに変え，关の6位に フッ素を導入し，加えて，7 位側鎖として種々のアルキル 基やシクロアルキル基を導入した化合物(1) を合成した . 兴の結果，抗菌活性は既存ニューキノロン系抗菌薬と同程 度にまで改善されたが, 尿中回収率が低く（代謝を受け易 (と推定）並びに急性毒性が強かったことから，更に置換 基変換を行い, 1-aminocyclopropyl 基を 7 位に導入した。 本化合物 (2) は, マウスにおける体内動態（静脈内投与で の血中濃度, 脳内移行性および尿中回収率) も良好で, け いれん誘発作用 (脳室内投与) および急性毒性（静脈内投 与) も改善された . 更に , 最適化を行い，オキサジン環を 導入した化合物が，CPFXや OFLXに匹敵する強い抗菌 活性と幅広い抗菌スペクトルを示し, 静脈内投与において 高い血中濃度を示した . また , 本化合物は CPFXや OFLX よりけいれん誘発作用, 急性毒性および細胞毒性か弱く, 細菌特有の DNA gyrase とヒトなどの哺乳類の topoisom- erase II 阻害作用における選択性が高かった . 更に , マウ ス実験的全身感染症モデルに対しても良好な゙治療効果を示 した．また，光学活性体 $\mathrm{S}$ 体 (PZFX) が R 体に比べ強い 抗菌力を示したことから $\mathrm{S}$ 体を選択した .

\section{3. 薬理試験成績}

（1）各種臨床分離株に対する抗菌活性（表 2)

PZFX は各種グラム陽性および陰性菌, 抗酸菌, マイコ プラズマ, リケッチアなど幅広い病原微生物に抗菌活性を 示し, また, 各種耐性菌に対しても良好な結果が得られて いる。

以下に弚の詳細を述べる .

(1)好気性，通性嫌気性菌に対する抗菌活性

各種耐性菌を除くグラム陽性菌に対するPZFXの $\mathrm{MIC}_{50}$ は 0.2〜 6.25 $\mu \mathrm{g} / \mathrm{mL}$ であり, $\mathrm{MIC}_{80}$ は 0.2〜100 $\mu \mathrm{g}$ $/ \mathrm{mL}$ であった . 各種グラム陰性菌に対する $\mathrm{PZFX} の \mathrm{MIC}_{50}$

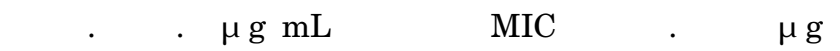
$\mathrm{mL}$ であった .

本斉に高度而性な株 $(\mathrm{MIC} \geqq 100 \mu \mathrm{g} / \mathrm{mL})$ が Enterococcus faecalis (30.2\%), Enterococcus faeccium (20.8\%) およびPseudomonas aeruginosa (13.7\%) において 10\% 以上認められたが, 兴の他の菌種では $10 \%$ 以下であった . (2)嫌気性菌に対する抗菌活性 
Table 2 (1) Antibacterial activity of pazufloxacin against clinical isolates

\begin{tabular}{|c|c|c|c|c|c|c|c|}
\hline \multirow{2}{*}{ Organism } & \multirow{2}{*}{$\begin{array}{l}\text { Number } \\
\text { of Strains }\end{array}$} & \multirow{2}{*}{ Drug } & \multicolumn{5}{|c|}{$\operatorname{MIC}(\mu \mathrm{g} / \mathrm{mL})^{\mathrm{a})}$} \\
\hline & & & & ange & $50 \%$ & $80 \%$ & $90 \%$ \\
\hline $\begin{array}{c}\text { Staphylococcus } \\
\text { aureus }\end{array}$ & $\begin{array}{r}144 \\
88 \\
89 \\
24 \\
100 \\
\end{array}$ & $\begin{array}{l}\text { PZFX } \\
\text { CAZ } \\
\text { IPM } \\
\text { GM } \\
\text { CPFX }\end{array}$ & $\begin{aligned} \leqq & 0.05 \\
& 0.39 \\
\leqq & 0.05 \\
& 0.1 \\
& 0.2\end{aligned}$ & $\begin{array}{l}->100 \\
-\quad>100 \\
-\quad 100 \\
->100 \\
-\quad>100\end{array}$ & $\begin{array}{c}0.2 \\
12.5 \\
\leqq \\
0.05 \\
0.2 \\
0.39 \\
\end{array}$ & $\begin{aligned} & 12.5 \\
&> 100 \\
& \leqq 0.05 \\
& 0.39 \\
& 0.78\end{aligned}$ & $\begin{array}{c}12.5 \\
>100 \\
12.5 \\
25 \\
3.13\end{array}$ \\
\hline MSSA & $\begin{array}{l}46 \\
46 \\
40 \\
40 \\
40\end{array}$ & $\begin{array}{l}\text { PZFX } \\
\text { CAZ } \\
\text { IPM } \\
\text { GM } \\
\text { CPFX }\end{array}$ & $\begin{aligned} & 0.1 \\
& 0.78 \\
\leqq & 0.05 \\
\leqq & 0.05 \\
& 0.1\end{aligned}$ & $\begin{array}{lc}- & 6.25 \\
- & 25 \\
- & 0.2 \\
- & 3.13 \\
- & 12.5\end{array}$ & $\begin{aligned} & 0.2 \\
& 12.5 \\
& \leq 0.05 \\
& 0.2 \\
& 0.39\end{aligned}$ & $\begin{array}{r}0.2 \\
12.5 \\
\leqq \\
0.05 \\
0.78 \\
0.78\end{array}$ & $\begin{aligned} & 0.39 \\
& 12.5 \\
& \leqq 0.05 \\
& 0.78 \\
& 0.78\end{aligned}$ \\
\hline $\begin{array}{l}\text { Staphylococcus } \\
\text { epidermidis }\end{array}$ & $\begin{array}{r}202 \\
100 \\
126 \\
49 \\
151\end{array}$ & $\begin{array}{l}\text { PZFX } \\
\text { CAZ } \\
\text { IPM } \\
\text { GM } \\
\text { CPFX }\end{array}$ & $\begin{aligned} & 0.2 \\
& 0.78 \\
\leqq & 0.05 \\
\leqq & 0.05 \\
\leqq & 0.05\end{aligned}$ & $\begin{array}{l}->100 \\
->100 \\
-\quad 100 \\
->100 \\
-\quad>100\end{array}$ & $\begin{array}{l}3.13 \\
12.5 \\
0.2 \\
0.2 \\
3.13\end{array}$ & $\begin{array}{l}12.5 \\
25 \\
12.5 \\
50 \\
25\end{array}$ & $\begin{array}{r}25 \\
50 \\
25 \\
100 \\
50\end{array}$ \\
\hline $\begin{array}{c}\text { Coagulase-negative } \\
\text { Staphylococci } \\
\text { (CNS) }\end{array}$ & $\begin{array}{l}67 \\
67 \\
67 \\
67 \\
67\end{array}$ & $\begin{array}{l}\text { PZFX } \\
\text { CAZ } \\
\text { IPM } \\
\text { GM } \\
\text { CPFX }\end{array}$ & $\begin{aligned} & 0.2 \\
& 0.39 \\
\leqq & 0.05 \\
\leqq & 0.05 \\
& 0.1\end{aligned}$ & $\begin{array}{lr}- & 100 \\
- & >100 \\
- & >100 \\
- & >100 \\
- & >100\end{array}$ & $\begin{array}{c}6.25 \\
25 \\
0.39 \\
25 \\
3.13\end{array}$ & $\begin{array}{c}12.5 \\
50 \\
3.13 \\
100 \\
25\end{array}$ & $\begin{array}{c}12.5 \\
100 \\
50 \\
100 \\
50\end{array}$ \\
\hline $\begin{array}{l}\text { Streptococcus } \\
\text { agalactiae }\end{array}$ & $\begin{array}{l}51 \\
51 \\
38 \\
38 \\
38\end{array}$ & $\begin{array}{l}\text { PZFX } \\
\text { CAZ } \\
\text { IPM } \\
\text { GM } \\
\text { CPFX }\end{array}$ & $\begin{array}{ll} & 1.56 \\
0.2 \\
\leq & 0.05 \\
3.13 \\
0.39\end{array}$ & $\begin{array}{cc}- & 12.5 \\
- & 3.13 \\
- & \leqq 0.05 \\
- & 100 \\
- & 1.56\end{array}$ & $\begin{aligned} & 3.13 \\
& 0.78 \\
& \leq 0.05 \\
& 50 \\
& 0.78\end{aligned}$ & $\begin{array}{r}6.25 \\
0.78 \\
\leqq 0.05 \\
50 \\
0.78\end{array}$ & $\begin{array}{r}6.25 \\
0.78 \\
\leqq \\
0.05 \\
50 \\
1.56\end{array}$ \\
\hline $\begin{array}{l}\text { Streptococcus } \\
\text { pyogenes }\end{array}$ & $\begin{array}{l}29 \\
29 \\
27 \\
27 \\
27\end{array}$ & $\begin{array}{l}\text { PZFX } \\
\text { CAZ } \\
\text { IPM } \\
\text { GM } \\
\text { CPFX }\end{array}$ & $\begin{aligned} & 0.78 \\
\leqq & 0.05 \\
\leqq & 0.05 \\
1.56 & \\
& 0.2\end{aligned}$ & $\begin{array}{lc}- & 25 \\
- & 1.56 \\
- & \leqq \\
- & 0.05 \\
- & 6.25 \\
- & 12.5\end{array}$ & $\begin{aligned} & 6.25 \\
& 0.2 \\
& \leqq 0.05 \\
& 3.13 \\
& 1.56\end{aligned}$ & $\begin{array}{c}12.5 \\
0.78 \\
\leqq 0.05 \\
6.25 \\
6.25 \\
\end{array}$ & $\begin{array}{r}12.5 \\
1.56 \\
\leqq \\
0.05 \\
6.25 \\
6.25\end{array}$ \\
\hline $\begin{array}{l}\text { Streptococcus } \\
\text { pneumoniae }\end{array}$ & $\begin{array}{l}141 \\
141 \\
66 \\
43 \\
66\end{array}$ & $\begin{array}{l}\text { PZFX } \\
\text { CAZ } \\
\text { IPM } \\
\text { GM } \\
\text { CPFX }\end{array}$ & $\begin{aligned} & 0.78 \\
\leqq & 0.05 \\
\leqq & 0.05 \\
& 0.78 \\
& 0.1\end{aligned}$ & $\begin{array}{lc}- & 100 \\
- & 12.5 \\
- & 0.39 \\
- & 25 \\
- & 50\end{array}$ & $\begin{array}{r}3.13 \\
0.39 \\
\leqq \\
0.05 \\
6.25 \\
0.78 \\
\end{array}$ & $\begin{aligned} & 3.13 \\
& 3.13 \\
& \leqq 0.05 \\
& 12.5 \\
& 1.56\end{aligned}$ & $\begin{array}{c}3.13 \\
6.25 \\
0.2 \\
12.5 \\
3.13\end{array}$ \\
\hline $\begin{array}{l}\text { Enterococcus } \\
\text { faecalis }\end{array}$ & $\begin{array}{l}315 \\
290 \\
151 \\
151 \\
176\end{array}$ & $\begin{array}{l}\text { PZFX } \\
\text { CAZ } \\
\text { IPM } \\
\text { GM } \\
\text { CPFX }\end{array}$ & $\begin{array}{c}0.39 \\
25 \\
0.39 \\
3.13 \\
0.39\end{array}$ & $\begin{array}{l}->100 \\
->100 \\
-\quad 6.25 \\
->100 \\
->100\end{array}$ & $\begin{array}{c}3.13 \\
>100 \\
1.56 \\
12.5 \\
1.56\end{array}$ & $\begin{array}{c}100 \\
>100 \\
3.13 \\
>100 \\
25\end{array}$ & $\begin{array}{c}>100 \\
>100 \\
3.13 \\
>100 \\
50\end{array}$ \\
\hline $\begin{array}{l}\text { Enterococcus } \\
\text { faecium }\end{array}$ & $\begin{array}{l}48 \\
48 \\
38 \\
38 \\
38\end{array}$ & $\begin{array}{l}\text { PZFX } \\
\text { CAZ } \\
\text { IPM } \\
\text { GM } \\
\text { CPFX }\end{array}$ & $\begin{array}{l}1.56 \\
3.13 \\
0.2 \\
3.13 \\
0.39\end{array}$ & $\begin{array}{l}->100 \\
->100 \\
->100 \\
->100 \\
->100\end{array}$ & $\begin{array}{r}6.25 \\
>100 \\
>100 \\
6.25 \\
3.13\end{array}$ & $\begin{array}{l}100 \\
>100 \\
>100 \\
\frac{12.5}{25}\end{array}$ & $\begin{array}{r}>100 \\
>100 \\
>100 \\
>100 \\
50\end{array}$ \\
\hline $\begin{array}{l}\text { Enterococcus } \\
\text { avium }\end{array}$ & $\begin{array}{l}15 \\
15 \\
9 \\
9 \\
9\end{array}$ & $\begin{array}{l}\text { PZFX } \\
\text { CAZ } \\
\text { IPM } \\
\text { GM } \\
\text { CPFX }\end{array}$ & $\begin{array}{l}1.56 \\
25 \\
0.39 \\
1.56 \\
0.39 \\
\end{array}$ & $\begin{array}{rr}- & >100 \\
- & >100 \\
- & >100 \\
- & >100 \\
- & 50\end{array}$ & $\begin{array}{c}3.13 \\
100 \\
1.56 \\
3.13 \\
0.78\end{array}$ & $\begin{array}{r}6.25 \\
>100 \\
>100 \\
6.25 \\
6.25\end{array}$ & $\begin{array}{r}12.5 \\
>100 \\
>100 \\
>100 \\
50\end{array}$ \\
\hline Escherichia coli & $\begin{array}{l}354 \\
329 \\
224 \\
204 \\
249\end{array}$ & $\begin{array}{l}\text { PZFX } \\
\text { CAZ } \\
\text { IPM } \\
\text { GM } \\
\text { CPFX }\end{array}$ & $\begin{array}{l}\leqq 0.05 \\
\leqq 0.05 \\
\leqq 0.05 \\
0.1 \\
\leqq 0.05\end{array}$ & $\begin{array}{lr}- & 25 \\
- & 25 \\
- & >100 \\
- & >100 \\
- & 50\end{array}$ & $\begin{aligned} \leqq & 0.05 \\
& 0.2 \\
& 0.2 \\
& 0.78 \\
\leqq & 0.05\end{aligned}$ & $\begin{array}{ll} & 0.1 \\
& 0.39 \\
& 0.2 \\
1.56 & \\
\leq & 0.05\end{array}$ & $\begin{array}{l}1.56 \\
1.56 \\
0.39 \\
1.56 \\
0.1\end{array}$ \\
\hline $\begin{array}{c}\text { Citrobacter } \\
\text { freundii }\end{array}$ & $\begin{array}{r}117 \\
92 \\
74 \\
74 \\
99\end{array}$ & $\begin{array}{l}\text { PZFX } \\
\text { CAZ } \\
\text { IPM } \\
\text { GM } \\
\text { CPFX }\end{array}$ & $\begin{aligned} \leqq & 0.05 \\
\leqq & 0.05 \\
& 0.1 \\
& 0.2 \\
\leqq & 0.05\end{aligned}$ & $\begin{array}{lc}- & 100 \\
- & 100 \\
- & 3.13 \\
- & 50 \\
- & 25\end{array}$ & $\begin{array}{l}0.1 \\
0.78 \\
0.78 \\
0.78 \\
\leqq \\
0.05\end{array}$ & $\begin{array}{c}0.78 \\
50 \\
0.78 \\
0.78 \\
0.39\end{array}$ & $\begin{array}{c}6.25 \\
100 \\
0.78 \\
1.56 \\
6.25\end{array}$ \\
\hline
\end{tabular}

${ }^{a}$ Inoculum size: $10^{6} \mathrm{CFU} / \mathrm{mL}$ PZFX: pazufloxacin, CAZ: ceftazidime, IPM: imipenem, GM: gentamicin, CPFX: ciprofloxacin 
Table 2 (2) Antibacterial activity of pazufloxacin against clinical isolates

\begin{tabular}{|c|c|c|c|c|c|c|c|}
\hline \multirow{2}{*}{ Organism } & \multirow{2}{*}{$\begin{array}{c}\text { Number } \\
\text { of Strains }\end{array}$} & \multirow{2}{*}{ Drug } & \multicolumn{5}{|c|}{$\operatorname{MIC}(\mu \mathrm{g} / \mathrm{mL})^{a)}$} \\
\hline & & & & ange & $50 \%$ & $80 \%$ & $90 \%$ \\
\hline $\begin{array}{l}\text { Enterobacter } \\
\text { cloacae }\end{array}$ & $\begin{array}{r}137 \\
112 \\
99 \\
99 \\
124 \\
\end{array}$ & $\begin{array}{l}\text { PZFX } \\
\text { CAZ } \\
\text { IPM } \\
\text { GM } \\
\text { CPFX }\end{array}$ & $\begin{aligned} \leqq & 0.05 \\
\leqq & 0.05 \\
& 0.1 \\
& 0.2 \\
\leqq & 0.05\end{aligned}$ & $\begin{array}{lr}- & 100 \\
- & >100 \\
- & 50 \\
- & >100 \\
- & 50 \\
\end{array}$ & $\begin{array}{r}\leq 0.05 \\
0.78 \\
0.39 \\
0.39 \\
\leq 0.05\end{array}$ & $\begin{array}{c}0.1 \\
50 \\
0.78 \\
0.78 \\
\leqq \\
0.05 \\
\end{array}$ & $\begin{array}{c}1.56 \\
>100 \\
1.56 \\
0.78 \\
0.78 \\
\end{array}$ \\
\hline $\begin{array}{c}\text { Klebsiella } \\
\text { pneumoniae }\end{array}$ & $\begin{array}{l}194 \\
169 \\
140 \\
120 \\
165\end{array}$ & $\begin{array}{l}\text { PZFX } \\
\text { CAZ } \\
\text { IPM } \\
\text { GM } \\
\text { CPFX }\end{array}$ & $\begin{array}{l}\leqq 0.05 \\
\leqq 0.05 \\
\leqq 0.05 \\
\\
0.1 \\
\leqq 0.05\end{array}$ & $\begin{array}{ll} & 1.56 \\
- & 3.13 \\
- & 3.13 \\
- & 1.56 \\
- & 3.13\end{array}$ & $\begin{aligned} \leqq & 0.05 \\
& 0.2 \\
& 0.2 \\
& 0.39 \\
\leqq & 0.05\end{aligned}$ & $\begin{array}{r}\leqq \\
0.05 \\
0.39 \\
0.39 \\
0.78 \\
\leqq 0.05\end{array}$ & $\begin{array}{l}0.1 \\
0.39 \\
0.39 \\
0.78 \\
0.1\end{array}$ \\
\hline $\begin{array}{c}\text { Klebsiella } \\
\text { oxytoca }\end{array}$ & $\begin{array}{r}18 \\
18 \\
7 \\
7 \\
7\end{array}$ & $\begin{array}{l}\text { PZFX } \\
\text { CAZ } \\
\text { IPM } \\
\text { GM } \\
\text { CPFX }\end{array}$ & $\begin{aligned} \leqq & 0.05 \\
\leqq & 0.05 \\
& 0.2 \\
& 0.39 \\
\leqq & 0.05\end{aligned}$ & $\begin{array}{lr}- & 100 \\
- & 3.13 \\
- & 3.13 \\
- & 0.78 \\
- & \leqq \\
\end{array}$ & $\begin{aligned} \leqq & 0.05 \\
& 0.1 \\
& 0.2 \\
& 0.39 \\
\leqq & 0.05\end{aligned}$ & $\begin{array}{ll} & 1.56 \\
& 0.2 \\
& 0.39 \\
& 0.78 \\
\leqq & 0.05 \\
\end{array}$ & $\begin{array}{r}6.25 \\
3.13 \\
3.13 \\
0.78 \\
\leqq 0.05 \\
\end{array}$ \\
\hline $\begin{array}{c}\text { Serratia } \\
\text { marcescens }\end{array}$ & $\begin{array}{r}112 \\
112 \\
81 \\
81 \\
81 \\
\end{array}$ & $\begin{array}{l}\text { PZFX } \\
\text { CAZ } \\
\text { IPM } \\
\text { GM } \\
\text { CPFX }\end{array}$ & $\begin{aligned} \leqq & 0.05 \\
& 0.1 \\
& 0.2 \\
\leqq & 0.05 \\
\leqq & 0.05\end{aligned}$ & $\begin{array}{lr}- & >100 \\
- & >100 \\
- & >100 \\
- & 50 \\
- & >100 \\
\end{array}$ & $\begin{array}{l}0.78 \\
3.13 \\
1.56 \\
0.78 \\
1.56 \\
\end{array}$ & $\begin{array}{c}3.13 \\
50 \\
3.13 \\
12.5 \\
6.25 \\
\end{array}$ & $\begin{array}{c}6.25 \\
100 \\
6.25 \\
12.5 \\
12.5\end{array}$ \\
\hline $\begin{array}{l}\text { Proteus } \\
\text { mirabilis }\end{array}$ & $\begin{array}{l}45 \\
45 \\
32 \\
32 \\
32 \\
\end{array}$ & $\begin{array}{l}\text { PZFX } \\
\text { CAZ } \\
\text { IPM } \\
\text { GM } \\
\text { CPFX }\end{array}$ & $\begin{aligned} \leqq & 0.05 \\
\leqq & 0.05 \\
& 0.2 \\
& 0.39 \\
\leqq & 0.05\end{aligned}$ & $\begin{array}{cc}- & 1.56 \\
- & 0.39 \\
- & 6.25 \\
- & >100 \\
- & 0.1\end{array}$ & $\begin{aligned} \leq & 0.05 \\
& 0.1 \\
& 3.13 \\
& 0.78 \\
\leq & 0.05\end{aligned}$ & $\begin{array}{ll}\leqq & 0.05 \\
& 0.1 \\
& 3.13 \\
& 1.56 \\
\leqq & 0.05 \\
\end{array}$ & $\begin{array}{l}0.1 \\
0.1 \\
3.13 \\
1.56 \\
0.1 \\
\end{array}$ \\
\hline $\begin{array}{l}\text { Proteus } \\
\text { vulgaris }\end{array}$ & $\begin{array}{l}33 \\
33 \\
29 \\
29 \\
29\end{array}$ & $\begin{array}{l}\text { PZFX } \\
\text { CAZ } \\
\text { IPM } \\
\text { GM } \\
\text { CPFX }\end{array}$ & $\begin{aligned} \leqq & 0.05 \\
\leqq & 0.05 \\
& 0.2 \\
& 0.2 \\
\leqq & 0.05\end{aligned}$ & $\begin{array}{ll}- & 6.25 \\
- & 0.78 \\
- & 6.25 \\
- & 6.25 \\
- & 100\end{array}$ & $\begin{array}{r}\leqq 0.05 \\
\leqq 0.05 \\
1.56 \\
0.39 \\
\leqq 0.05\end{array}$ & $\begin{array}{ll}\leqq & 0.05 \\
& 0.1 \\
& 3.13 \\
& 0.78 \\
\leqq & 0.05\end{array}$ & $\begin{aligned} \leqq & 0.05 \\
& 0.2 \\
& 3.13 \\
& 0.78 \\
\leqq & 0.05\end{aligned}$ \\
\hline $\begin{array}{l}\text { Providencia } \\
\quad \text { rettgeri }\end{array}$ & $\begin{array}{l}40 \\
40 \\
35 \\
35 \\
35\end{array}$ & $\begin{array}{l}\text { PZFX } \\
\text { CAZ } \\
\text { IPM } \\
\text { GM } \\
\text { CPFX }\end{array}$ & $\begin{aligned} \leqq & 0.05 \\
\leqq & 0.05 \\
& 0.39 \\
& 0.1 \\
\leqq & 0.05\end{aligned}$ & $\begin{array}{lc}- & 100 \\
- & 50 \\
- & 3.13 \\
- & 6.25 \\
- & 50\end{array}$ & $\begin{aligned} \leqq & 0.05 \\
& 0.1 \\
& 1.56 \\
& 0.78 \\
\leqq & 0.05\end{aligned}$ & $\begin{array}{l}0.39 \\
0.78 \\
1.56 \\
1.56 \\
0.2 \\
\end{array}$ & $\begin{array}{l}3.13 \\
1.56 \\
3.13 \\
3.13 \\
0.78 \\
\end{array}$ \\
\hline $\begin{array}{c}\text { Morganella } \\
\text { morganii }\end{array}$ & $\begin{array}{l}44 \\
44 \\
36 \\
36 \\
36 \\
\end{array}$ & $\begin{array}{l}\text { PZFX } \\
\text { CAZ } \\
\text { IPM } \\
\text { GM } \\
\text { CPFX }\end{array}$ & $\begin{aligned} \leqq & 0.05 \\
\leqq & 0.05 \\
& 0.39 \\
& 0.2 \\
\leqq & 0.05\end{aligned}$ & $\begin{array}{lc}- & 50 \\
- & 100 \\
- & 6.25 \\
- & >100 \\
- & 100\end{array}$ & $\begin{aligned} \leqq & 0.05 \\
& 0.2 \\
& 1.56 \\
& 0.39 \\
\leqq & 0.05\end{aligned}$ & $\begin{array}{c}0.39 \\
12.5 \\
3.13 \\
0.78 \\
0.78 \\
\end{array}$ & $\begin{array}{l}3.13 \\
25 \\
3.13 \\
1.56 \\
6.25 \\
\end{array}$ \\
\hline $\begin{array}{l}\text { Pseudomonas } \\
\text { aeruginosa }\end{array}$ & $\begin{array}{l}351 \\
326 \\
246 \\
227 \\
271\end{array}$ & $\begin{array}{l}\text { PZFX } \\
\text { CAZ } \\
\text { IPM } \\
\text { GM } \\
\text { CPFX }\end{array}$ & $\begin{aligned} & 0.1 \\
\leqq & 0.05 \\
& 0.1 \\
& 0.39 \\
\leqq & 0.05\end{aligned}$ & $\begin{array}{l}->100 \\
-\quad>100 \\
-\quad 100 \\
->100 \\
-\quad>100\end{array}$ & $\begin{array}{l}0.78 \\
3.13 \\
3.13 \\
6.25 \\
0.39\end{array}$ & $\begin{array}{l}25 \\
12.5 \\
6.25 \\
12.5 \\
6.25\end{array}$ & $\begin{array}{r}100 \\
50 \\
25 \\
50 \\
50\end{array}$ \\
\hline $\begin{array}{l}\text { Acinetobacter } \\
\text { calcoaceticus }\end{array}$ & $\begin{array}{l}65 \\
65 \\
56 \\
56 \\
56\end{array}$ & $\begin{array}{l}\text { PZFX } \\
\text { CAZ } \\
\text { IPM } \\
\text { GM } \\
\text { CPFX }\end{array}$ & $\begin{aligned} \leqq & 0.05 \\
& 0.78 \\
\leqq & 0.05 \\
& 0.2 \\
\leqq & 0.05\end{aligned}$ & $\begin{array}{lc}- & 100 \\
- & 100 \\
- & 6.25 \\
- & >100 \\
- & 3.13\end{array}$ & $\begin{array}{l}0.39 \\
3.13 \\
0.2 \\
0.78 \\
0.2 \\
\end{array}$ & $\begin{array}{l}0.39 \\
6.25 \\
0.39 \\
3.13 \\
0.39 \\
\end{array}$ & $\begin{array}{c}0.78 \\
25 \\
0.39 \\
12.5 \\
0.39 \\
\end{array}$ \\
\hline $\begin{array}{l}\text { Haemophilus } \\
\text { influenzae }\end{array}$ & $\begin{array}{r}135 \\
135 \\
88 \\
88 \\
88\end{array}$ & $\begin{array}{l}\text { PZFX } \\
\text { CAZ } \\
\text { IPM } \\
\text { GM } \\
\text { CPFX }\end{array}$ & $\begin{aligned} \leqq & 0.05 \\
\leqq & 0.05 \\
& 0.1 \\
& 0.2 \\
\leqq & 0.05\end{aligned}$ & 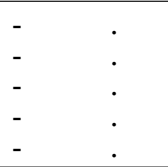 & $\begin{aligned} \leqq & 0.05 \\
& 0.2 \\
& 0.78 \\
& 1.56 \\
\leqq & 0.05\end{aligned}$ & $\begin{array}{r}\leqq \\
0.05 \\
0.39 \\
1.56 \\
3.13 \\
\leqq 0.05 \\
\end{array}$ & $\begin{array}{r}\leq 0.05 \\
0.39 \\
3.13 \\
3.13 \\
\leqq 0.05\end{array}$ \\
\hline Legionella $\mathrm{sp}$. & $\begin{array}{l}13 \\
13 \\
13 \\
13 \\
13\end{array}$ & $\begin{array}{l}\text { PZFX } \\
\text { CAZ } \\
\text { IPM } \\
\text { GM } \\
\text { CPFX }\end{array}$ & $\begin{array}{l}0.00625 \\
0.05 \\
0.025 \\
0.39 \\
0.0125\end{array}$ & $\begin{array}{l}0.025 \\
1.56 \\
0.2 \\
1.56 \\
0.05\end{array}$ & $\begin{array}{l}0.0125 \\
0.2 \\
0.05 \\
0.78 \\
0.025\end{array}$ & $\begin{array}{l}- \\
- \\
- \\
- \\
-\end{array}$ & $\begin{array}{l}0.025 \\
0.39 \\
0.05 \\
1.56 \\
0.05\end{array}$ \\
\hline
\end{tabular}

${ }^{a}$ Inoculum size: $10^{6} \mathrm{CFU} / \mathrm{mL}$ PZFX: pazufloxacin, CAZ: ceftazidime, IPM: imipenem, GM: gentamicin, CPFX: ciprofloxacin 
Table 2 (3) Antibacterial activity of pazufloxacin against clinical isolates

\begin{tabular}{|c|c|c|c|c|c|c|c|c|}
\hline \multirow{2}{*}{ Organism } & \multirow{2}{*}{$\begin{array}{l}\text { Number } \\
\text { of Strains }\end{array}$} & \multirow{2}{*}{ Drug } & \multicolumn{6}{|c|}{$\operatorname{MIC}(\mu \mathrm{g} / \mathrm{mL})^{\mathrm{a})}$} \\
\hline & & & \multicolumn{3}{|c|}{ Range } & $\begin{array}{r}50 \% \\
\leqq 0.05\end{array}$ & $\begin{array}{r}80 \% \\
0.1\end{array}$ & $90 \%$ \\
\hline $\begin{array}{l}\text { Moraxella } \\
\text { catarrhalis }\end{array}$ & $\begin{array}{l}79 \\
79 \\
66 \\
66 \\
66\end{array}$ & $\begin{array}{l}\text { PZFX } \\
\text { CAZ } \\
\text { IPM } \\
\text { GM } \\
\text { CPFX }\end{array}$ & $\begin{array}{l}\text { \0.05 } \\
\leqq 0.05 \\
\leqq 0.05 \\
\leqq 0.05 \\
\leqq 0.05\end{array}$ & $\begin{array}{l}\text { - } \\
- \\
- \\
-\end{array}$ & $\begin{array}{l}0.2 \\
0.39 \\
0.2 \\
0.78 \\
0.1\end{array}$ & $\begin{aligned} \leqq & 0.05 \\
& 0.1 \\
& 0.1 \\
& 0.39 \\
\leqq & 0.05\end{aligned}$ & $\begin{array}{l}0.1 \\
0.1 \\
0.2 \\
0.39 \\
0.1\end{array}$ & $\begin{array}{l}0.1 \\
0.2 \\
0.2 \\
0.39 \\
0.1\end{array}$ \\
\hline $\begin{array}{l}\text { Bacteroides } \\
\text { fragilis }\end{array}$ & $\begin{array}{r}142 \\
142 \\
142 \\
41 \\
142\end{array}$ & $\begin{array}{l}\text { PZFX } \\
\text { CAZ } \\
\text { IPM } \\
\text { GM } \\
\text { CPFX }\end{array}$ & $\begin{array}{r}1.56 \\
6.25 \\
\leqq 0.05 \\
>100 \\
1.56\end{array}$ & $\begin{array}{l}- \\
- \\
- \\
-\end{array}$ & $\begin{array}{c}>100 \\
>100 \\
12.5 \\
>100 \\
>100\end{array}$ & $\begin{array}{c}6.25 \\
25 \\
0.2 \\
>100 \\
6.25\end{array}$ & $\begin{array}{c}6.25 \\
>100 \\
0.39 \\
>100 \\
25\end{array}$ & $\begin{array}{c}25 \\
>100 \\
0.78 \\
>100 \\
50\end{array}$ \\
\hline Prevotella spp. & $\begin{array}{l}72 \\
72 \\
72 \\
13 \\
72\end{array}$ & $\begin{array}{l}\text { PZFX } \\
\text { CAZ } \\
\text { IPM } \\
\text { GM } \\
\text { CPFX }\end{array}$ & 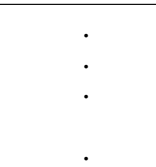 & $\begin{array}{l}- \\
- \\
-\end{array}$ & $\begin{array}{r}>100 \\
>100 \\
25 \\
>100 \\
>100\end{array}$ & $\begin{array}{r}1.56 \\
1.56 \\
\leqq 0.05 \\
>100 \\
1.56\end{array}$ & $\begin{array}{c}6.25 \\
100 \\
0.1 \\
>100 \\
12.5\end{array}$ & $\begin{array}{c}50 \\
>100 \\
0.2 \\
>100 \\
50\end{array}$ \\
\hline $\begin{array}{c}\text { Mycobacterium } \\
\text { tuberculosis }\end{array}$ & $\begin{array}{l}15 \\
15 \\
15 \\
15\end{array}$ & $\begin{array}{l}\text { PZFX } \\
\text { CPFX } \\
\text { SPFX } \\
\text { RIF } \\
\end{array}$ & 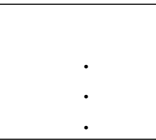 & $\begin{array}{l}- \\
- \\
-\end{array}$ & $\begin{array}{l}8 \\
2 \\
1 \\
1\end{array}$ & $\begin{aligned} & 4 \\
& 0.5 \\
& 0.125 \\
& \leqq 0.063 \\
&\end{aligned}$ & $\begin{array}{l}- \\
- \\
- \\
-\end{array}$ & $\begin{array}{l}4 \\
1 \\
0.25 \\
0.25 \\
\end{array}$ \\
\hline $\begin{array}{c}\text { Mycobacterium } \\
\text { avium }\end{array}$ & $\begin{array}{l}22 \\
22 \\
22 \\
22\end{array}$ & $\begin{array}{l}\text { PZFX } \\
\text { CPFX } \\
\text { SPFX } \\
\text { RIF }\end{array}$ & $\begin{array}{l}2 \\
0.25 \\
0.125 \\
4\end{array}$ & - & $\begin{array}{r}>128 \\
32 \\
16 \\
>128\end{array}$ & $\begin{array}{r}16 \\
2 \\
2 \\
64\end{array}$ & $\begin{array}{l}- \\
- \\
- \\
-\end{array}$ & $\begin{array}{r}64 \\
8 \\
8 \\
128\end{array}$ \\
\hline $\begin{array}{c}\text { Mycobacterium } \\
\text { intracellulare }\end{array}$ & $\begin{array}{l}22 \\
22 \\
22 \\
22\end{array}$ & $\begin{array}{l}\text { PZFX } \\
\text { CPFX } \\
\text { SPFX } \\
\text { RIF }\end{array}$ & $\begin{array}{l}2 \\
0.25 \\
0.5 \\
0.125\end{array}$ & - & $\begin{array}{r}128 \\
16 \\
16 \\
128\end{array}$ & $\begin{array}{l}4 \\
1 \\
1 \\
1\end{array}$ & $\begin{array}{l}- \\
- \\
- \\
-\end{array}$ & $\begin{array}{r}16 \\
16 \\
8 \\
32\end{array}$ \\
\hline $\begin{array}{l}\text { Mycoplasma } \\
\text { pneumoniae }\end{array}$ & $\begin{array}{l}10 \\
10 \\
10 \\
10\end{array}$ & $\begin{array}{l}\text { PZFX } \\
\text { CPFX } \\
\text { SPFX } \\
\text { EM }\end{array}$ & $\begin{array}{l}4 \\
0.5 \\
0.0625 \\
0.0039\end{array}$ & $\begin{array}{l}- \\
- \\
-\end{array}$ & $\begin{array}{l}8 \\
2 \\
0.125 \\
0.0156\end{array}$ & $\begin{array}{l}8 \\
1 \\
0.125 \\
0.0156\end{array}$ & $\begin{array}{l}- \\
- \\
- \\
-\end{array}$ & $\begin{array}{l}8 \\
1 \\
0.125 \\
0.0156\end{array}$ \\
\hline
\end{tabular}

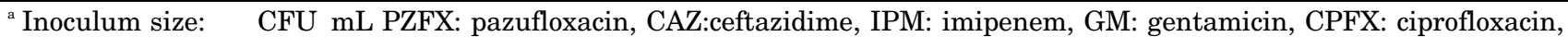
SPFX: sparfloxacin, RIF: rifampicin, EM: erythromycin

Bacteroides fragilis に対する PZFXの $\mathrm{MIC}_{50}$ おひび $\mathrm{MIC}_{80}$ は共に6.25 $\mathrm{g} / \mathrm{mL}$ で, Prevotella 属に対する $\mathrm{PZFX}$ の $\mathrm{MIC}_{50}$ および $\mathrm{MIC}_{80}$ は $1.56 \mu \mathrm{g} / \mathrm{mL}$ および 6.25 $\mu \mathrm{g} / \mathrm{mL}$ であった . B. fragilis, Prevotella 属における本剂 に高度耐性な株（MIC $\geqq 100 \mu \mathrm{g} / \mathrm{mL})$ は $10.0 \%$ 以下であ った。

(3)抗酸菌およびマイコプラズマに対する抗菌活性

結核菌を含む抗酸菌並びにマイコプラズマに対する $\mathrm{PZFX}$ の $\mathrm{MIC}_{50}$ および $\mathrm{MIC}_{90}$ は , 4 16 $\mu \mathrm{g} / \mathrm{mL}$ および 4 〜 $64 \mu \mathrm{g} / \mathrm{mL}$ であった .

(2) 各種耐性菌に対する抗菌活性 (表 3)

各種抗菌薬耐性 methicillin-resistant Staphylococcus aureus (MRSA) に対する $\mathrm{PZFX} の \mathrm{MIC}_{50}$ は 0.2 12.5 $\mu \mathrm{g} / \mathrm{mL}$ で, $\mathrm{MIC}_{80}$ は 0.39〜12.5 $\mu \mathrm{g} / \mathrm{mL}$ であった . penicillin-resistant Streptococcus pneumoniae (PRSP) およ びvancomycin-resistant enterococci (VRE) に対する

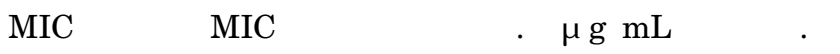

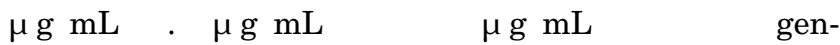

tamicin (GM)，OFLX2 剂耐性 MRSA および CAZ 耐性 Serratia marcescens に対する PZFXの $\mathrm{MIC}_{50}$ は感受性

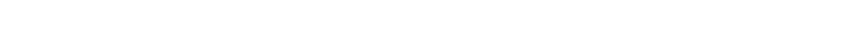
に対しては各種薬物感受性株と同程度の $\mathrm{MIC}_{50}$ を示した。 cefazolin (CEZ) 而性 Escherichia coli , CAZ 而性 Enterobacter cloacae, extended spectrum $\beta$-lactamase (ESBL) 産生 Klebsiella pneumoniae，CAZ 而性 Citrobacter freundii, ampicillin ( $\mathrm{ABPC}$ ) 耐性 Haemophilus influenzae , $\beta$-lactamase negative $\mathrm{ABPC}$ resistant $H$. influenzae (BLNAR)，imipenem (IPM)，GM，CAZ 而性 P. aeruginosa, IPM 分解性 $\beta$-lactamase 産生 $S$. marcescens およ び $P$. aeruginosa に対する $\mathrm{MIC}_{50}$ および $\mathrm{MIC}_{80}$ は，乥れ ぞれ 0.0125 (一部菌種で 0.78 ) 12.5 $\mu \mathrm{g} / \mathrm{mL}$ および 0.025

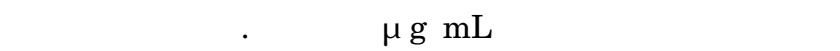
における本剂に高度耐性な株 $(\mathrm{MIC} \geqq 100 \mu \mathrm{g} / \mathrm{mL})$ は 10.0\% 以下であった .

(3) 特殊な微生物に対する抗菌活性 (表 4)

炭疽菌, クラミジア，Q熱リケッチアの標準株に対す 
Table 3 (1) Antibacterial activity of pazufloxacin against clinical isolates

\begin{tabular}{|c|c|c|c|c|c|c|c|}
\hline \multirow{2}{*}{ Organism } & \multirow{2}{*}{$\begin{array}{c}\text { Number } \\
\text { of Strains }\end{array}$} & \multirow{2}{*}{ Drug } & \multicolumn{5}{|c|}{$\operatorname{MIC}(\mu \mathrm{g} / \mathrm{mL})^{\mathrm{a})}$} \\
\hline & & & \multicolumn{2}{|c|}{ Range } & $50 \%$ & $80 \%$ & $90 \%$ \\
\hline MRSA & $\begin{array}{r}119 \\
59 \\
104 \\
58 \\
118\end{array}$ & $\begin{array}{l}\text { PZFX } \\
\text { CAZ } \\
\text { IPM } \\
\text { GM } \\
\text { CPFX }\end{array}$ & $\begin{array}{l}\quad 0.1 \\
25 \\
\leqq \\
0.05 \\
0.1 \\
0.2\end{array}$ & $\begin{array}{l}->100 \\
->100 \\
-\quad 100 \\
->100 \\
-\quad>100\end{array}$ & $\begin{array}{c}6.25 \\
>100 \\
25 \\
12.5 \\
12.5\end{array}$ & $\begin{array}{c}12.5 \\
>100 \\
50 \\
100 \\
100\end{array}$ & $\begin{array}{r}50 \\
>100 \\
100 \\
>100 \\
>100 \\
\end{array}$ \\
\hline $\begin{array}{l}\text { GM-resistant } \\
\text { MRSA }^{\text {b) }}\end{array}$ & $\begin{array}{l}32 \\
32 \\
32 \\
32 \\
32\end{array}$ & $\begin{array}{l}\text { PZFX } \\
\text { CAZ } \\
\text { IPM } \\
\text { GM } \\
\text { CPFX }\end{array}$ & $\begin{array}{l}0.2 \\
25 \\
0.1 \\
6.25 \\
0.1\end{array}$ & $\begin{array}{lc}- & 0.39 \\
- & >100 \\
- & >100 \\
- & 100 \\
- & 3.13\end{array}$ & $\begin{array}{c}0.2 \\
>100 \\
50 \\
25 \\
1.56\end{array}$ & $\begin{array}{c}0.39 \\
>100 \\
50 \\
50 \\
1.56\end{array}$ & $\begin{array}{c}0.39 \\
>100 \\
100 \\
50 \\
1.56\end{array}$ \\
\hline $\begin{array}{l}\text { GM, OFLX } \\
\text {-resistant } \\
\text { MRSA }^{\mathrm{b}, \mathrm{c})}\end{array}$ & $\begin{array}{l}26 \\
26 \\
26 \\
26 \\
26\end{array}$ & $\begin{array}{l}\text { PZFX } \\
\text { CAZ } \\
\text { IPM } \\
\text { GM } \\
\text { CPFX }\end{array}$ & $\begin{array}{c}1.56 \\
50 \\
0.2 \\
6.25 \\
12.5 \\
\end{array}$ & $\begin{array}{lr}- & 100 \\
- & >100 \\
- & 100 \\
- & >100 \\
- & >100 \\
\end{array}$ & $\begin{array}{c}12.5 \\
>100 \\
25 \\
50 \\
50\end{array}$ & $\begin{array}{c}12.5 \\
>100 \\
50 \\
50 \\
100\end{array}$ & $\begin{array}{r}25 \\
>100 \\
50 \\
100 \\
100 \\
\end{array}$ \\
\hline $\begin{array}{c}\text { PCG intermediately } \\
\text {-resistant } \\
\text { Streptococcus }^{\text {pneumoniae }} \\
\text { pr) }^{\text {d) }}\end{array}$ & $\begin{array}{l}13 \\
13 \\
13 \\
13 \\
13\end{array}$ & $\begin{array}{l}\text { PZFX } \\
\text { CAZ } \\
\text { IPM } \\
\text { GM } \\
\text { CPFX }\end{array}$ & $\begin{array}{l}1.56 \\
0.78 \\
0.0125 \\
6.25 \\
0.1 \\
\end{array}$ & $\begin{array}{lc}- & 3.13 \\
- & 12.5 \\
- & 0.2 \\
- & 12.5 \\
- & 1.56\end{array}$ & $\begin{array}{c}1.56 \\
3.13 \\
0.05 \\
12.5 \\
0.39 \\
\end{array}$ & $\begin{array}{c}3.13 \\
6.25 \\
0.2 \\
12.5 \\
0.78 \\
\end{array}$ & $\begin{array}{c}3.13 \\
12.5 \\
0.2 \\
12.5 \\
0.78\end{array}$ \\
\hline $\begin{array}{l}\text { PCG-resistant } \\
\text { Streptococcus } \\
\text { pneumoniae }^{\text {e) }} \\
\quad \text { (PRSP) }\end{array}$ & $\begin{array}{l}13 \\
13 \\
13 \\
13 \\
13\end{array}$ & $\begin{array}{l}\text { PZFX } \\
\text { CAZ } \\
\text { IPM } \\
\text { GM } \\
\text { CPFX }\end{array}$ & $\begin{array}{l}1.56 \\
6.25 \\
0.2 \\
6.25 \\
0.39 \\
\end{array}$ & $\begin{array}{lc}- & >25 \\
- & 25 \\
- & 0.39 \\
- & 12.5 \\
- & >25\end{array}$ & $\begin{array}{c}1.56 \\
12.5 \\
0.2 \\
12.5 \\
0.78 \\
\end{array}$ & $\begin{array}{c}3.13 \\
25 \\
0.39 \\
12.5 \\
1.56 \\
\end{array}$ & $\begin{array}{c}3.13 \\
25 \\
0.39 \\
12.5 \\
1.56 \\
\end{array}$ \\
\hline $\begin{array}{c}\text { Vancomycin-resistant } \\
\text { Enterococci } \\
\text { (VRE) }\end{array}$ & $\begin{array}{l}24 \\
24 \\
24 \\
24 \\
24 \\
24\end{array}$ & $\begin{array}{l}\text { PZFX } \\
\text { CAZ } \\
\text { IPM } \\
\text { VCM } \\
\text { TEIC } \\
\text { CPFX }\end{array}$ & $\begin{array}{c}1.56 \\
>100 \\
0.39 \\
6.25 \\
0.2 \\
0.39 \\
\end{array}$ & $\begin{array}{l}->100 \\
-\quad>100 \\
->100 \\
-\quad>100 \\
-\quad 50 \\
\end{array}$ & $\begin{array}{c}6.25 \\
>100 \\
>100 \\
>100 \\
0.39 \\
3.13 \\
\end{array}$ & $\begin{aligned} & 50 \\
&> 100 \\
&> 100 \\
&> 100 \\
& 12.5 \\
& 50\end{aligned}$ & $\begin{array}{r}100 \\
>100 \\
>100 \\
>100 \\
50 \\
50\end{array}$ \\
\hline $\begin{array}{l}\text { CEZ-resistant }{ }^{\mathrm{f})} \\
\text { Escherichia coli }\end{array}$ & $\begin{array}{l}30 \\
30 \\
30 \\
30 \\
30\end{array}$ & $\begin{array}{l}\text { PZFX } \\
\text { CAZ } \\
\text { IPM } \\
\text { GM } \\
\text { CPFX }\end{array}$ & $\begin{array}{l}0.025 \\
0.1 \\
0.2 \\
0.39 \\
0.0125 \\
\end{array}$ & $\begin{array}{ll}- & 0.78 \\
- & 6.25 \\
- & 0.78 \\
- & 1.56 \\
- & 0.78\end{array}$ & $\begin{array}{l}0.025 \\
0.78 \\
0.2 \\
0.78 \\
0.025\end{array}$ & $\begin{array}{l}0.05 \\
3.13 \\
0.2 \\
0.78 \\
0.025\end{array}$ & $\begin{array}{l}0.1 \\
3.13 \\
0.39 \\
1.56 \\
0.1\end{array}$ \\
\hline $\begin{array}{l}\text { CAZ-resistant } \\
\text { Citrobacter } \\
\text { freundii }^{\text {g) }}\end{array}$ & $\begin{array}{l}22 \\
22 \\
22 \\
22 \\
22\end{array}$ & $\begin{array}{l}\text { PZFX } \\
\text { CAZ } \\
\text { IPM } \\
\text { GM } \\
\text { CPFX }\end{array}$ & $\begin{array}{l}0.0125 \\
6.25 \\
0.2 \\
0.1 \\
0.00625\end{array}$ & $\begin{array}{lc}- & 6.25 \\
- & >100 \\
- & 3.13 \\
- & 100 \\
- & 12.5\end{array}$ & $\begin{array}{c}0.1 \\
100 \\
0.39 \\
0.39 \\
0.1\end{array}$ & $\begin{array}{c}0.39 \\
100 \\
0.78 \\
0.78 \\
0.2 \\
\end{array}$ & $\begin{array}{c}0.39 \\
>100 \\
0.78 \\
6.25 \\
0.39\end{array}$ \\
\hline $\begin{array}{l}\text { CAZ-resistant } \\
\text { Enterobacter } \\
\text { cloacae }^{\mathrm{g})}\end{array}$ & $\begin{array}{l}17 \\
17 \\
17 \\
17 \\
17\end{array}$ & $\begin{array}{l}\text { PZFX } \\
\text { CAZ } \\
\text { IPM } \\
\text { GM } \\
\text { CPFX }\end{array}$ & $\begin{array}{l}0.025 \\
25 \\
0.2 \\
0.2 \\
0.0125\end{array}$ & $\begin{array}{lc}- & 0.39 \\
- & >100 \\
- & 3.13 \\
- & >100 \\
- & 0.78\end{array}$ & $\begin{array}{c}0.05 \\
100 \\
0.39 \\
0.39 \\
0.05\end{array}$ & $\begin{array}{r}0.1 \\
>100 \\
1.56 \\
1.56 \\
0.05\end{array}$ & $\begin{array}{c}0.2 \\
>100 \\
1.56 \\
100 \\
0.1\end{array}$ \\
\hline $\begin{array}{c}\text { Extended spectrum } \\
\beta \text {-lactamase producing } \\
\text { Klebsiella } \\
\text { Pneumoniae }\end{array}$ & $\begin{array}{l}19 \\
19 \\
19 \\
19\end{array}$ & $\begin{array}{l}\text { PZFX } \\
\text { CAZ } \\
\text { IPM } \\
\text { CPFX }\end{array}$ & $\begin{aligned} & 0.0125 \\
& 0.05 \\
& 0.1 \\
\leqq & 0.00625\end{aligned}$ & $\begin{array}{lc}- & 0.78 \\
- & 25 \\
- & 0.78 \\
- & 1.56\end{array}$ & $\begin{array}{l}0.025 \\
1.56 \\
0.2 \\
0.025\end{array}$ & $\begin{array}{l}0.2 \\
6.25 \\
0.39 \\
0.1\end{array}$ & $\begin{array}{l}0.39 \\
25 \\
0.78 \\
0.39\end{array}$ \\
\hline $\begin{array}{l}\text { CAZ-resistant } \\
\text { Serratia } \\
\text { marcescens }\end{array}$ & $\begin{array}{l}24 \\
24 \\
24 \\
24 \\
24\end{array}$ & $\begin{array}{l}\text { PZFX } \\
\text { CAZ } \\
\text { IPM } \\
\text { GM } \\
\text { CPFX }\end{array}$ & $\begin{array}{l}0.2 \\
6.25 \\
0.2 \\
0.2 \\
0.2\end{array}$ & $\begin{array}{lc}= & 25 \\
- & >100 \\
- & 6.25 \\
- & >100 \\
- & 25\end{array}$ & $\begin{array}{l}3.13 \\
25 \\
3.13 \\
3.13 \\
6.25\end{array}$ & $\begin{array}{c}12.5 \\
100 \\
3.13 \\
50 \\
12.5\end{array}$ & $\begin{array}{c}12.5 \\
100 \\
6.25 \\
50 \\
25\end{array}$ \\
\hline $\begin{array}{l}\text { IPM-hydrolyzing } \\
\beta \text {-lactamase } \\
\text { producing } \\
\text { Serratia } \\
\text { Marcescens }\end{array}$ & $\begin{array}{l}\frac{11}{11} \\
11 \\
11 \\
11\end{array}$ & $\begin{array}{l}\text { PZFX } \\
\text { CAZ } \\
\text { IPM } \\
\text { GM } \\
\text { CPFX }\end{array}$ & $\begin{array}{c}\leq 0.78 \\
>100 \\
50 \\
3.13 \\
\leqq 0.78\end{array}$ & $\begin{array}{lc}- & 6.25 \\
- & >100 \\
- & >100 \\
- & 25 \\
- & 6.25\end{array}$ & $\begin{array}{c}\leq 0.78 \\
>100 \\
>100 \\
6.25 \\
1.56\end{array}$ & $\begin{array}{c}\leq 0.78 \\
>100 \\
>100 \\
12.5 \\
1.56\end{array}$ & $\begin{array}{c}3.13 \\
>100 \\
>100 \\
12.5 \\
6.25\end{array}$ \\
\hline
\end{tabular}

${ }^{a}$ Inoculum size: $10^{6} \mathrm{CFU} / \mathrm{mL},{ }^{\text {b) }}$ gentamicin (GM) $\mathrm{MIC} \geqq 3.13 \mu \mathrm{g} / \mathrm{mL},{ }^{\mathrm{c}}$ ofloxacin (OFLX) MIC $\geqq 6.25 \mu \mathrm{g} / \mathrm{mL},{ }^{\mathrm{d})} \mathrm{Penicillin} \mathrm{G}$ (PCG) $\mathrm{MIC} \geqq 0.1 \sim 0.78 \mu \mathrm{g} / \mathrm{mL},{ }^{\mathrm{e})} \mathrm{PCG} \mathrm{MIC} \geqq 1.56 \mu \mathrm{g} / \mathrm{mL}$, ${ }^{\mathrm{f}}$ cefazolin (CEZ) MIC $\geqq 6.25 \mu \mathrm{g} / \mathrm{mL}$, ${ }^{\mathrm{g}}$ ceftazidime (CAZ) MIC $\geqq 6.25 \mu \mathrm{g} / \mathrm{mL}$. PZFX: pazufloxacin, IPM: imipenem, GM: gentamicin, CPFX: ciprofloxacin, VCM: vancomycin, TEIC: teicoplanin 
Table 3 (2) Antibacterial activity of pazufloxacin against clinical isolates

\begin{tabular}{|c|c|c|c|c|c|c|c|}
\hline \multirow{2}{*}{ Organism } & \multirow{2}{*}{$\begin{array}{l}\text { Number } \\
\text { of Strains }\end{array}$} & \multirow{2}{*}{ Drug } & \multicolumn{5}{|c|}{$\operatorname{MIC}(\mu \mathrm{g} / \mathrm{mL})^{\mathrm{a})}$} \\
\hline & & & \multicolumn{2}{|c|}{ Range } & \multirow{2}{*}{$\begin{array}{c}50 \% \\
0.39 \\
3.13 \\
25 \\
1.56 \\
0.2\end{array}$} & \multirow{2}{*}{\begin{tabular}{|l|}
$80 \%$ \\
0.78 \\
3.13 \\
25 \\
3.13 \\
0.2
\end{tabular}} & \multirow{2}{*}{$\begin{array}{c}90 \% \\
0.78 \\
6.25 \\
25 \\
3.13 \\
0.39 \\
\end{array}$} \\
\hline $\begin{array}{l}\text { IPM-resistant } \\
\text { Pseudomonas } \\
\text { aeruginosa }^{\text {b) }}\end{array}$ & $\begin{array}{l}30 \\
30 \\
30 \\
30 \\
30\end{array}$ & $\begin{array}{l}\text { PZFX } \\
\text { CAZ } \\
\text { IPM } \\
\text { GM } \\
\text { CPFX }\end{array}$ & $\begin{array}{l}0.2 \\
1.56 \\
1.56 \\
0.78 \\
0.1\end{array}$ & $\begin{array}{ll}- & 50 \\
- & 25 \\
- & 50 \\
- & 25 \\
- & 50\end{array}$ & & & \\
\hline $\begin{array}{l}\text { GM-resistant } \\
\text { Pseudomonas } \\
\text { aeruginosa }^{\text {c) }}\end{array}$ & $\begin{array}{l}26 \\
26 \\
26 \\
26 \\
26\end{array}$ & $\begin{array}{l}\text { PZFX } \\
\text { CAZ } \\
\text { IPM } \\
\text { GM } \\
\text { CPFX }\end{array}$ & $\begin{array}{l}0.2 \\
3.13 \\
0.39 \\
3.13 \\
0.2\end{array}$ & $\begin{array}{lc}- & 12.5 \\
- & 100 \\
- & 3.13 \\
- & 12.5 \\
- & 25\end{array}$ & $\begin{array}{l}0.39 \\
3.13 \\
1.56 \\
6.25 \\
0.2\end{array}$ & $\begin{array}{c}0.78 \\
12.5 \\
1.56 \\
12.5 \\
0.39\end{array}$ & $\begin{array}{c}0.78 \\
25 \\
1.56 \\
12.5 \\
0.39\end{array}$ \\
\hline $\begin{array}{c}\text { IPM, GM-resistant } \\
\text { Pseudomonas } \\
\text { aeruginosa }^{\mathrm{b}, \mathrm{c})}\end{array}$ & $\begin{array}{l}16 \\
16 \\
16 \\
16 \\
16\end{array}$ & $\begin{array}{l}\text { PZFX } \\
\text { CAZ } \\
\text { IPM } \\
\text { GM } \\
\text { CPFX }\end{array}$ & $\begin{array}{l}0.39 \\
1.56 \\
1.56 \\
6.25 \\
0.1\end{array}$ & $\begin{array}{lc}- & 50 \\
- & 6.25 \\
- & 25 \\
- & >100 \\
- & 50\end{array}$ & $\begin{array}{l}0.39 \\
3.13 \\
6.25 \\
6.25 \\
0.39\end{array}$ & $\begin{array}{l}0.78 \\
3.13 \\
25 \\
25 \\
0.39\end{array}$ & $\begin{array}{l}3.13 \\
6.25 \\
25 \\
25 \\
0.78\end{array}$ \\
\hline $\begin{array}{c}\text { IPM, GM, CAZ } \\
\text {-resistant } \\
\text { Pseudomonas }^{\text {aeruginosa }}{ }^{\mathrm{b}, \mathrm{c}, \mathrm{d})}\end{array}$ & $\begin{array}{l}21 \\
21 \\
21 \\
21 \\
21\end{array}$ & $\begin{array}{l}\text { PZFX } \\
\text { CAZ } \\
\text { IPM } \\
\text { GM } \\
\text { CPFX }\end{array}$ & $\begin{array}{l}0.39 \\
6.25 \\
1.56 \\
3.13 \\
0.2\end{array}$ & $\begin{array}{lr}- & >100 \\
- & >100 \\
- & 50 \\
- & >100 \\
- & 50\end{array}$ & $\begin{array}{l}0.78 \\
25 \\
12.5 \\
6.25 \\
0.39\end{array}$ & $\begin{array}{r}50 \\
>100 \\
25 \\
100 \\
50\end{array}$ & $\begin{array}{r}50 \\
>100 \\
50 \\
>100 \\
50\end{array}$ \\
\hline $\begin{array}{l}\text { IPM-hydrolyzing } \\
\beta \text {-lactamase } \\
\text { producing } \\
\text { Pseudomonas } \\
\text { aeruginosa }\end{array}$ & $\begin{array}{l}9 \\
9 \\
9 \\
9 \\
9\end{array}$ & $\begin{array}{l}\text { PZFX } \\
\text { CAZ } \\
\text { IPM } \\
\text { GM } \\
\text { CPFX }\end{array}$ & $\begin{aligned} & 0.2 \\
&> 100 \\
& 12.5 \\
& 3.13 \\
& \leq 0.1\end{aligned}$ & $\begin{array}{lc}- & 0.78 \\
- & >100 \\
- & >100 \\
- & >100 \\
- & 0.39\end{array}$ & $\begin{aligned} & 0.39 \\
> & 100 \\
> & 100 \\
> & 100 \\
\leqq & 0.1\end{aligned}$ & $\begin{aligned} & 0.39 \\
&> 100 \\
&> 100 \\
&> 100 \\
& 0.39\end{aligned}$ & $\begin{array}{c}0.78 \\
>100 \\
>100 \\
>100 \\
0.39\end{array}$ \\
\hline $\begin{array}{l}\text { ABPC-resistant } \\
\text { Haemophilus } \\
\text { influenzae }^{\text {e) }}\end{array}$ & $\begin{array}{l}21 \\
21 \\
21 \\
21 \\
21 \\
21\end{array}$ & $\begin{array}{l}\text { PZFX } \\
\text { CAZ } \\
\text { IPM } \\
\text { GM } \\
\text { CPFX } \\
\text { ABPC }\end{array}$ & $\begin{array}{l}0.0125 \\
0.1 \\
0.78 \\
0.78 \\
0.0125 \\
3.13 \\
\end{array}$ & $\begin{array}{lc} & 0.78 \\
- & 1.56 \\
- & 12.5 \\
- & 1.56 \\
- & 0.39 \\
\end{array}$ & $\begin{array}{l}0.0125 \\
0.2 \\
1.56 \\
0.78 \\
0.0125 \\
50\end{array}$ & $\begin{aligned} & 0.025 \\
& 0.39 \\
& 3.13 \\
& 1.56 \\
& 0.0125 \\
&>100\end{aligned}$ & $\begin{array}{l}0.025 \\
0.78 \\
6.25 \\
1.56 \\
0.0125 \\
>100 \\
\end{array}$ \\
\hline $\begin{array}{c}\beta \text {-lactamase negative } \\
\text { ABPC-resistant } \\
\text { Haemophilus } \\
\text { influenzae }{ }^{\text {e) }} \\
\text { (BLNAR) }\end{array}$ & $\begin{array}{l}26 \\
26 \\
26 \\
26\end{array}$ & $\begin{array}{l}\text { PZFX } \\
\text { CAZ } \\
\text { IPM } \\
\text { CPFX }\end{array}$ & $\begin{aligned} \leqq & 0.00625 \\
& 0.2 \\
& 0.39 \\
\leqq & 0.00625\end{aligned}$ & $\begin{array}{l}0.025 \\
0.78 \\
12.5 \\
0.025\end{array}$ & $\begin{aligned} & 0.0125 \\
& 0.39 \\
& 6.25 \\
\leqq & 0.00625\end{aligned}$ & $\begin{array}{l}0.025 \\
0.78 \\
12.5 \\
0.0125\end{array}$ & $\begin{array}{l}0.025 \\
0.78 \\
12.5 \\
0.0125\end{array}$ \\
\hline
\end{tabular}

${ }^{\mathrm{a})}$ Inoculum size: $10^{6} \mathrm{CFU} / \mathrm{mL},{ }^{\mathrm{b})} \mathrm{IPM} \mathrm{MIC} \geqq 1.56 \mu \mathrm{g} / \mathrm{mL},{ }^{\mathrm{c}} \mathrm{GM} \mathrm{MIC} \geqq 3.13 \mu \mathrm{g} / \mathrm{mL},{ }^{\mathrm{d})} \mathrm{CAZ} \mathrm{MIC} \geqq 6.25 \mu \mathrm{g} / \mathrm{mL},{ }^{\mathrm{e})} \mathrm{ABPC} \mathrm{MIC} \geqq$ $3.13 \mu \mathrm{g} / \mathrm{mL}$. PZFX: pazufloxacin, CAZ: ceftazidime, IPM: imipenem, GM: gentamicin, CPFX: ciprofloxacin, ABPC: ampicillin

Table 4 Antibacterial activity of PZFX against rare bacteria

\begin{tabular}{|c|c|c|}
\hline \multirow{2}{*}{ Organism } & \multicolumn{2}{|c|}{$\operatorname{MIC}(\mu \mathrm{g} / \mathrm{mL})$} \\
\hline & Pazufloxacin & Ciprofloxacin \\
\hline Bacillus anthracis & 0.05 & 0.05 \\
\hline $\begin{array}{l}\text { Chlamydia pneumo- } \\
\text { niae TW-183 }\end{array}$ & 4 & 0.5 \\
\hline $\begin{array}{l}\text { Coxiella burnetii } \\
\text { Nine Mile VR615* }\end{array}$ & 2 & 8 \\
\hline
\end{tabular}

る PZFX の抗菌活性を表 4 に示す . PZFX はこれらの微 生物にも抗菌活性を示し, MIC は 0.05〜 4 $\mu \mathrm{g} / \mathrm{mL}$ で, CPFXの1/4 から 8 倍であった .

(4) 細胞内取り込み菌に対する殺菌作用 (図 4)

P. aeruginosa S-2163をヒ卜好中球に取り込ませ , 1/4, 1, 4, $16 \mathrm{MIC}$ の PZFX, CAZ, IPM を作用させ , 好中球 内生菌数を測定した. 炎の結果, 好中球に取り込ませた $P$. aeruginosa に対し，CAZ，IPM は細胞内の菌に作用を示 さなかったが, PZFX は濃度依存的に細胞内生菌数を減少 させた .

\section{(5) 短時間殺菌効果 (表 5)}

各種グラム陽性および陰性菌に, 各被験薬の臨床用量投 与後の最高血中濃度の近似值として, $\mathrm{PZFX}$ では $8 \mu \mathrm{g} / \mathrm{mL}$ (PZFX $500 \mathrm{mg}, 30$ 分間点滴静注時) ,CAZ では $80 \mu \mathrm{g} / \mathrm{mL}$ 
Exposure for 2 hours

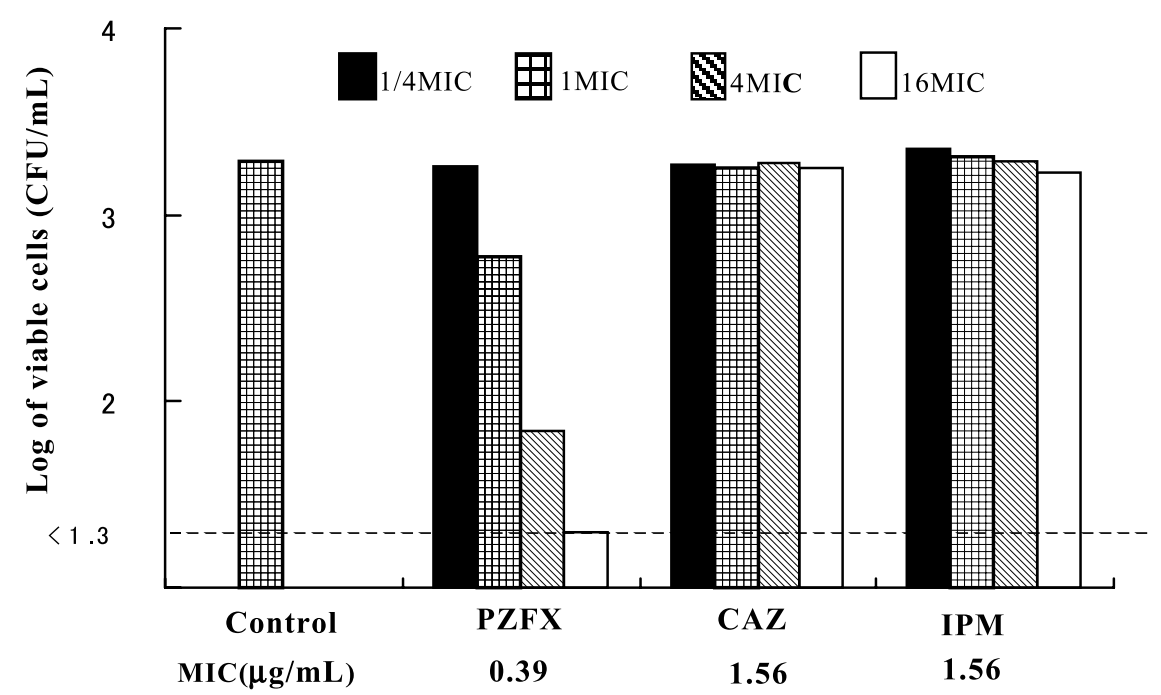

Fig. 4 Intracellular bactericidal activity of pazufloxacin against Pseudomonas aeruginosa. PZFX: pazufloxacin, CAZ: ceftazidime, IPM: imipenem

(CAZ $1 \mathrm{~g}, 1$ 時間点滴静注時) および IPM では $30 \mu \mathrm{g} / \mathrm{mL}$ (IPM/CS $500 \mathrm{mg}, 30$ 分間点滴静注時) を液体培地中で $37^{\circ} \mathrm{C}, 15$ 分間作用させた時の生菌数を測定した. 光の結 果，PZFXをS. pneumoniae，E. faecalisに15 分間作用 させた時は CAZ, IPM と同樣に菌数減少は見られなかっ たが, S. aureus ,E. coli , Proteus mirabilis ,S. marcescens，P. aeruginosa に 15 分間作用させた時は生菌数を 約 1/10〜1/80000 以下に減少させ,作用後の生菌数は CAZ, IPM より有意に少なかった .

\section{(6) Postantibiotic effect (PAE) (図 5)}

各種グラム陽性および陰性菌に，上記の短時間殺菌効果 検討時と同樣の試験方法にて PZFX , CAZ , IPM を液体 培地中で $37^{\circ} \mathrm{C}, 15$ 分間作用させ PAE を測定した . 兴の 結果，PZFXをS. aureus Smith，E. faecalis，S. pneumoniae に15 分間作用させた時, IPM より短いが約 0.5 時間〜2 時間の PAE が見られた，一方，グラム陰性菌の 場合，試験した 4 菌株 (E. coli TK-16，S. marcescens IID $620, P$. mirabilis IFO3849, $P$. aeruginosa S-495) に対 する PZFX の PAE は約 2 時間で，いずれも CAZ, IPM (約 1 時間以下) より有意に長かった .

(7) 作用機序 $($ 表 6,7$)$

S. aureus SA113より精製した DNA gyrase および topoisomerase IV, 並びにヒト由来 DNA topoisomerase II に対する PZFX の阻害活性 $\left(\mathrm{IC}_{50}\right)$ を測定した . PZFX
のS. aureus 由来 DNA gyrase および topoisomerase IV

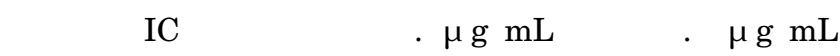
で,近似した值であった .一方, DNA gyrase および topoisomerase IV に対する CPFX の $\mathrm{IC}_{50}$ は光れぞれ $58.1 \mu \mathrm{g} /$ $\mathrm{mL}$ および $1.13 \mu \mathrm{g} / \mathrm{mL} て ゙$, topoisomerase $\mathrm{IV}$ を約 50 倍 強く阻害した . ヒト由来 DNA topoisomerase II に対する 阻害活性は PZFX および CPFX ともに弱く， $\mathrm{IC}_{50}$ は 800 $\mu \mathrm{g} / \mathrm{mL}$ 以上および $354 \mu \mathrm{g} / \mathrm{mL}$ であった . PZFX のヒト 由来 DNA topoisomerase II に対する $\mathrm{IC}_{50}$ は $S$. aureus 由来のDNA gyraseおよび topoisomerase IV に対する

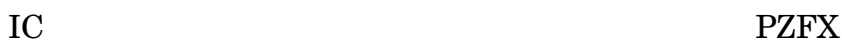
は細菌の topoisomerase を選択的に阻害した .

\section{4. 一般薬理試験成績}

\section{(1) けいれん誘発作用 (表 8)}

マウス脳室内に各種抗菌薬を単独投与, あるいはビフェ ニル酢酸を併用投与し，けいれんの有無を検討した結果， PZFX の痙攣誘発作用は他のキノロン系抗菌薬と比較して 最も弱かった . ビフェニル酢酸との併用では, 多くのキノ ロン系抗菌薬は単独投与時より低い用量でけいれんか誘発 されたが, PZFX は単独投与時とほとんど変わらなかった . 更にß-ラクタム系抗菌薬と比較しても，PZFXのけいれ ん誘発作用は弱かった。

(2) 血圧, 心拍数, ヒスタミン遊離に及ぼす影響(図 6) 
Table 5 Bactericidal activity of pazufloxacin

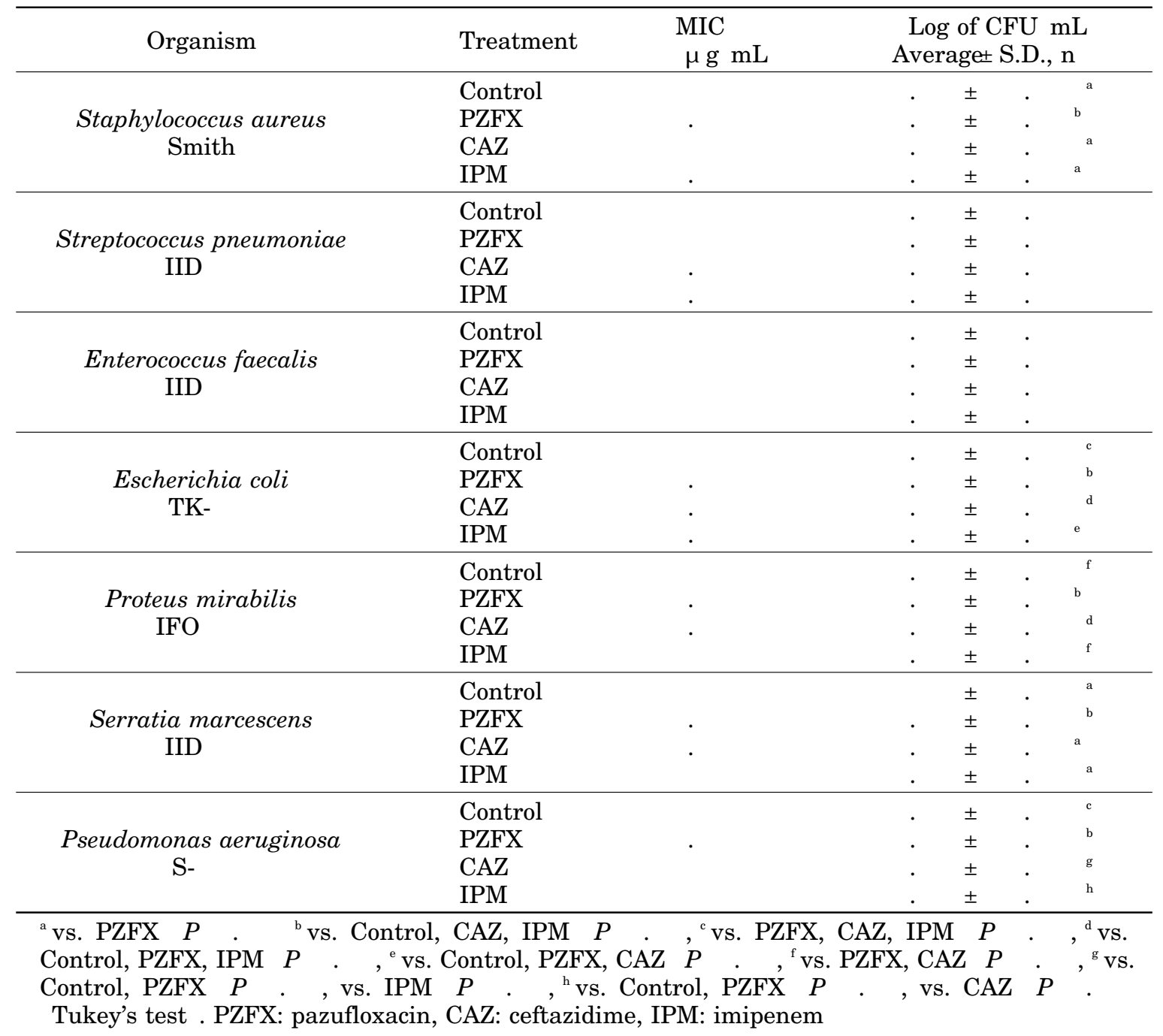

イヌに PZFX，CPFXおよび OFLXの $10 \mathrm{mg} / \mathrm{kg}$ を 50 $\mathrm{mg} /$ 分の速度で静脈内投与した時の血圧, 心拍数および血 漿中ヒスタミン濃度の変化を検討した。CPFX, OFLXで は投与中から血圧が急激に下降，心拍数も減少し，また， 血墏中ヒスタミン濃度は投与前より急激に上昇した。 PZFXではいずれの変化も認めなかった .

（3）投与局所での血管透過性六進作用 (表 9)

各種濃度の抗菌薬 $0.1 \mathrm{~mL}$ を皮内投与した直後に $2 \%$ Evans blue 溶液を静脈内投与し, 30 分後に漏出色素斑を 判定し，皮膚血管透過性亢進作用を検討した。PZFXは $1000 \mu \mathrm{g} / \mathrm{mL}$ 以下まで亢進させなかったが，CPFX および OFLX は $16 \mu \mathrm{g} / \mathrm{mL}$ 以上で血管透過性を亢進させた .こ れらの血管透過性六進作用は抗ヒスタミン薬投与により抑 制されたことから，投与局所におけるヒスタミンが遊離し
たために引き起こされたと推察され，PZFX のヒスタミン 遊離作用は投与局所においても CPFX および OFLXより 弱いものと考えられた .

\section{5. 薬物動態}

(1) ヒト血中濃度 (図 7)

本剂を健康成人に 30 分点滴静注にて単回投与した時の 血中濃度推移および血中薬物動態パラメータは図 7 の通り であり, 通常成人の 1 回投与量である $500 \mathrm{mg}$ 点滴静注後 の最高血中濃度 $(\mathrm{Cmax})$ は $11.0 \mu \mathrm{g} / \mathrm{mL}$ と高い值を示す ことが認められている. 本邦での同系統の注射用抗菌薬で ある $\mathrm{CPFX}$ 注 $300 \mathrm{mg}$ 単回投与時 (通常成人 1 回投与量) の Cmax およびAUC は，添付文書では光れ攵れ $3.33 \mu \mathrm{g} /$ $\mathrm{mL}, 7.49 \mu \mathrm{g} \cdot \mathrm{hr} / \mathrm{mL}$ とされており, 本剂 $500 \mathrm{mg}$ 点滴静 

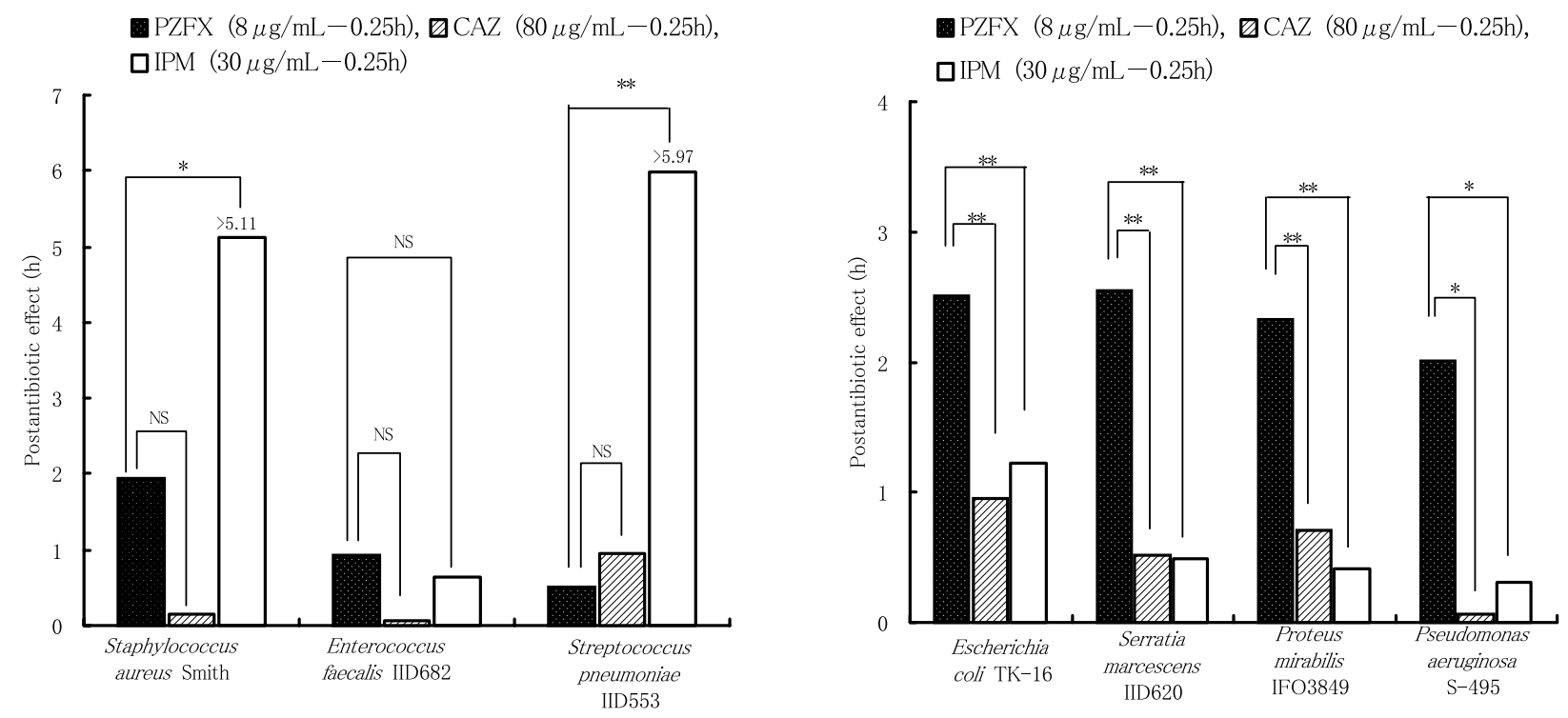

Fig. 5 In vitro postantibiotic effect of pazufloxacin. Data represent the mean. $(\mathrm{n}=3){ }^{*} P<0.05,{ }^{* *} P<0.01$, NS; Not significant (Dunnett method). PZFX: pazufloxacin, CAZ: ceftazidime, IPM: imipenem

Table 6 Inhibitory activities of pazufloxacin against DNA gyrase and DNA topoisomerase IV obtained from S.aureus SA113

\begin{tabular}{ccc}
\hline \multirow{2}{*}{ Drug } & \multicolumn{2}{c}{$\mathrm{IC}_{50}(\mu \mathrm{g} / \mathrm{mL})^{*}$} \\
\cline { 2 - 3 } & $\mathrm{Gyr}$ & Topo IV \\
\hline Pazufloxacin & 13.6 & 9.65 \\
Ciprofloxacin & 58.1 & 1.13 \\
\hline
\end{tabular}

${ }^{*}$ Average of three trials

Table 7 Inhibitory activities of pazufloxacin against DNA topoisomerase II from human placenta

\begin{tabular}{cc}
\hline Drug & $\mathrm{IC}_{50}(\mu \mathrm{mg} / \mathrm{mL})^{*}$ \\
\hline Pazufloxacin & $>800$ \\
Ciprofloxacin & 354 \\
\hline
\end{tabular}

* Average of three trials

注時の Cmax およびAUC は CPFX 注の約 3 倍であった . (2) ヒト組織内移行

本斉の組織移行性は以下の通りであり，良好な組織移行 か認められている .

喀痰・肺組織 : 1 回 $500 \mathrm{mg}, 30$ 分点滴静注時の最高喀痰
中濃度は点滴開始 0.5〜2.5 時間後に 2.49〜 $6.24 \mu \mathrm{g} / \mathrm{g}(\mathrm{n}$ =4) であり，また点滴開始 1.5 時間後の肺組織内濃度は 平均 $7.95 \mu \mathrm{g} / \mathrm{g}(\mathrm{n}=5)$ であつた .

胆道 : 1 回 $500 \mathrm{mg}, 30$ 分点滴静注時の胆管胆汁中濃度は 点滴開始 1.5 4.5 時間後に 5.47〜 $29.9 \mu \mathrm{g} / \mathrm{mL}(\mathrm{n}=3)$ で あり，また，胆囊組織内濃度は投与後1.0〜2.5 時間後に 9.85〜 35.5 $\mu \mathrm{g} / \mathrm{g} \quad(\mathrm{n}=4)$ であつた .

胸水・腹水: 1 回 $500 \mathrm{mg}, 60$ 分点滴静注時の胸水中濃度 は点滴開始 7 時間後に $1.43 \mu \mathrm{g} / \mathrm{mL}(\mathrm{n}=1), 1$ 回 $300 \mathrm{mg}$ ， 60 分点滴静注時の腹水中濃度は点滴開始 4 時間後に 1.87 $\mu \mathrm{g} / \mathrm{mL}(\mathrm{n}=1)$ を示した。

創膿汁・熱傷皮膚組織 : 1 回 $500 \mathrm{mg}, 30$ 分点滴静注時の 創膿汁中濃度は点滴開始 1.5 時間後に 2 例平均で $4.73 \mu \mathrm{g} /$ $\mathrm{mL}$ であり，また点滴開始 1.5 時間後の熱傷皮膚組織エス カ一部分の濃度は 4 例平均で $4.54 \mu \mathrm{g} / \mathrm{g}$ であった 。 女性性器組織: 1 回 $300 \mathrm{mg}, 30$ 分点滴静注時の女性性器 の各組織濃度は点滴開始 0.83 時間後で $5.00 \sim 13.9 \mu \mathrm{g} / \mathrm{g}(\mathrm{n}$ =5) であり, 骨盤死腔液中濃度は点滴開始 2 時間後の平 均で $3.18 \mu \mathrm{g} / \mathrm{mL}(\mathrm{n}=4)$ であった .

髄液 : 1 回 $500 \mathrm{mg}, 30$ 分点滴静注 1.5 時間後の髄液中濃 度は 3 例平均で $0.33 \mu \mathrm{g} / \mathrm{mL}$ であった 。

6. 臨床効果 (表 10)

(1) 疾患別臨床効果

各科領域の感染症に対する臨床効果を表 10 に示す . 有 
Table 8 Effect of pazufloxacin on the induction of convulsion in intracerebrally injected mice with biphenyl actic acid (BPAA)

\begin{tabular}{|c|c|c|c|c|c|c|c|c|c|c|}
\hline \multirow{3}{*}{ Drug } & \multirow{3}{*}{$\begin{array}{l}\text { With or } \\
\text { without } \\
\text { BPAA }^{a}\end{array}$} & \multicolumn{9}{|c|}{ Clonic convulsion positive mice/test mice } \\
\hline & & \multicolumn{9}{|c|}{ Dose (mg/body, i.c.) } \\
\hline & & 0.78 & 1.56 & 3.13 & 6.25 & 12.5 & 25 & 50 & 100 & 200 \\
\hline Pazufloxacin & $\begin{array}{l}- \\
+\end{array}$ & & & & & & & $\begin{array}{l}0 / 10 \\
0 / 10\end{array}$ & $\begin{array}{l}1 / 10 \\
4 / 10\end{array}$ & $\begin{array}{l}8 / 10 \\
8 / 10\end{array}$ \\
\hline Enoxacin & + & $4 / 10$ & $2 / 10$ & $9 / 10$ & $\begin{array}{l}0 / 10 \\
7 / 10\end{array}$ & $1 / 10$ & $8 / 10$ & $9 / 10$ & & \\
\hline Norfloxacin & + & $4 / 10$ & $8 / 10$ & $\begin{array}{l}0 / 10 \\
9 / 10\end{array}$ & $6 / 10$ & $10 / 10$ & & & & \\
\hline Ciprofloxacin & $\begin{array}{l}- \\
+ \\
-\end{array}$ & & & $4 / 10$ & $5 / 10$ & $\begin{array}{r}3 / 10 \\
10 / 10\end{array}$ & $\begin{array}{r}9 / 10 \\
10 / 10\end{array}$ & $10 / 10$ & & \\
\hline Ofloxacin & + & & & & & $\begin{array}{l}0 / 10 \\
1 / 10\end{array}$ & $\begin{array}{l}0 / 10 \\
2 / 10\end{array}$ & $\begin{array}{l}9 / 10 \\
9 / 10\end{array}$ & $9 / 10$ & \\
\hline Levofloxacin & + & & & & & $0 / 10$ & $\begin{array}{l}2 / 10 \\
4 / 10\end{array}$ & $\begin{array}{r}6 / 10 \\
10 / 10\end{array}$ & $10 / 10$ & \\
\hline Lomefloxacin & + & & & $1 / 10$ & $8 / 10$ & $\begin{array}{l}1 / 10 \\
6 / 10\end{array}$ & $\begin{array}{r}6 / 10 \\
10 / 10\end{array}$ & $10 / 10$ & $10 / 10$ & \\
\hline Fleroxacin & + & & & & & $1 / 10$ & $\begin{array}{l}0 / 10 \\
1 / 10\end{array}$ & $\begin{array}{l}4 / 10 \\
6 / 10\end{array}$ & $8 / 10$ & \\
\hline Sparfloxacin & + & & & & & $0 / 10$ & $\begin{array}{l}0 / 10 \\
1 / 10\end{array}$ & $\begin{array}{l}4 / 10 \\
2 / 10\end{array}$ & $7 / 10$ & \\
\hline Temafloxacin & + & & & & & $0 / 10$ & $\begin{array}{l}1 / 10 \\
1 / 10\end{array}$ & $\begin{array}{l}8 / 10 \\
9 / 10\end{array}$ & $10 / 10$ & \\
\hline Imipenem/Cilastatin & + & & & $2 / 10$ & $\begin{array}{l}2 / 10 \\
4 / 10\end{array}$ & $\begin{array}{l}9 / 10 \\
8 / 10\end{array}$ & $9 / 10$ & & & \\
\hline Panipenem/Betamipron & + & & & & $0 / 10$ & $\begin{array}{l}1 / 10 \\
8 / 10\end{array}$ & $\begin{array}{r}6 / 10 \\
10 / 10\end{array}$ & $\begin{array}{l}10 / 10 \\
10 / 10\end{array}$ & & \\
\hline Meropenem & + & & & & & & & & & $\begin{array}{l}0 / 10 \\
0 / 10\end{array}$ \\
\hline Benzylpenicillin & + & & & & & $\begin{array}{l}0 / 10 \\
0 / 10\end{array}$ & $\begin{array}{l}3 / 10 \\
2 / 10\end{array}$ & $\begin{array}{l}8 / 10 \\
7 / 10\end{array}$ & $\begin{array}{r}9 / 10 \\
10 / 10\end{array}$ & \\
\hline Cefazolin & + & & & & & $\begin{array}{l}1 / 10 \\
1 / 10 \\
\end{array}$ & $\begin{array}{l}5 / 10 \\
4 / 10 \\
\end{array}$ & $\begin{array}{l}9 / 10 \\
8 / 10 \\
\end{array}$ & $\begin{array}{l}10 / 10 \\
10 / 10\end{array}$ & \\
\hline
\end{tabular}

Animal: ICR strain (male, $\mathrm{n}=10),{ }^{\text {a) }}-$ : without BPAA, + : with BPAA $(1 \mu \mathrm{g} /$ body $)$

効性の解析対象全症例での有効率は 84.0\% (890/1060) で あり, 注射用抗菌薬か対象となる外科領域感染症, 呼吸器 感染症, 尿路感染症, 胆道感染症, 腹腔内感染症および産 婦人科領域感染症に対し，一部の疾患を除きほぼ $80 \%$ 以 上の有効率か認められた .この内，複杂倠性尿路感染症，細 菌性肺炎，慢性気道感染症では臨床第而相比較試験におい て，広域注射用セフェム系抗菌薬 CAZに対し，臨床効果 の有効率における非劣性が検証されている .

(2) 起炎菌別細菌学的効果 (表 11)

起炎菌別細菌学的効果を表 11 に示す. 起炎菌検出例に おける全解析対象例 744 例にて，菌陰性化率は 75.5\% (562
/744) であった . 菌種別では, Moraxella catarrhalis, $E$. coli ,Enterobacter spp., Serratia spp., Proteus spp. , Providencia spp. 各単独菌感染例においては, いずれも $100 \%$ の菌陰性化率であり，また，Staphylococcus spp.， Citrobacter spp., Klebsiella spp. ,H. influenzae 各単独 菌感染例においても $80 \%$ 以上の菌陰性化率が示された . S. pneumoniae の陰性化率は $71.6 \%$ (53/74) であった . (3) 前投薬無効例に対する臨床効果 (表 12)

各科領域の細菌感染症において, 前投薬無効例 (PZFX 投与直前に他の抗菌薬を 3 日以上投与して担当医師が無効 と判断し, 細菌感染症の症状, 所見が明確な症例) に対す 


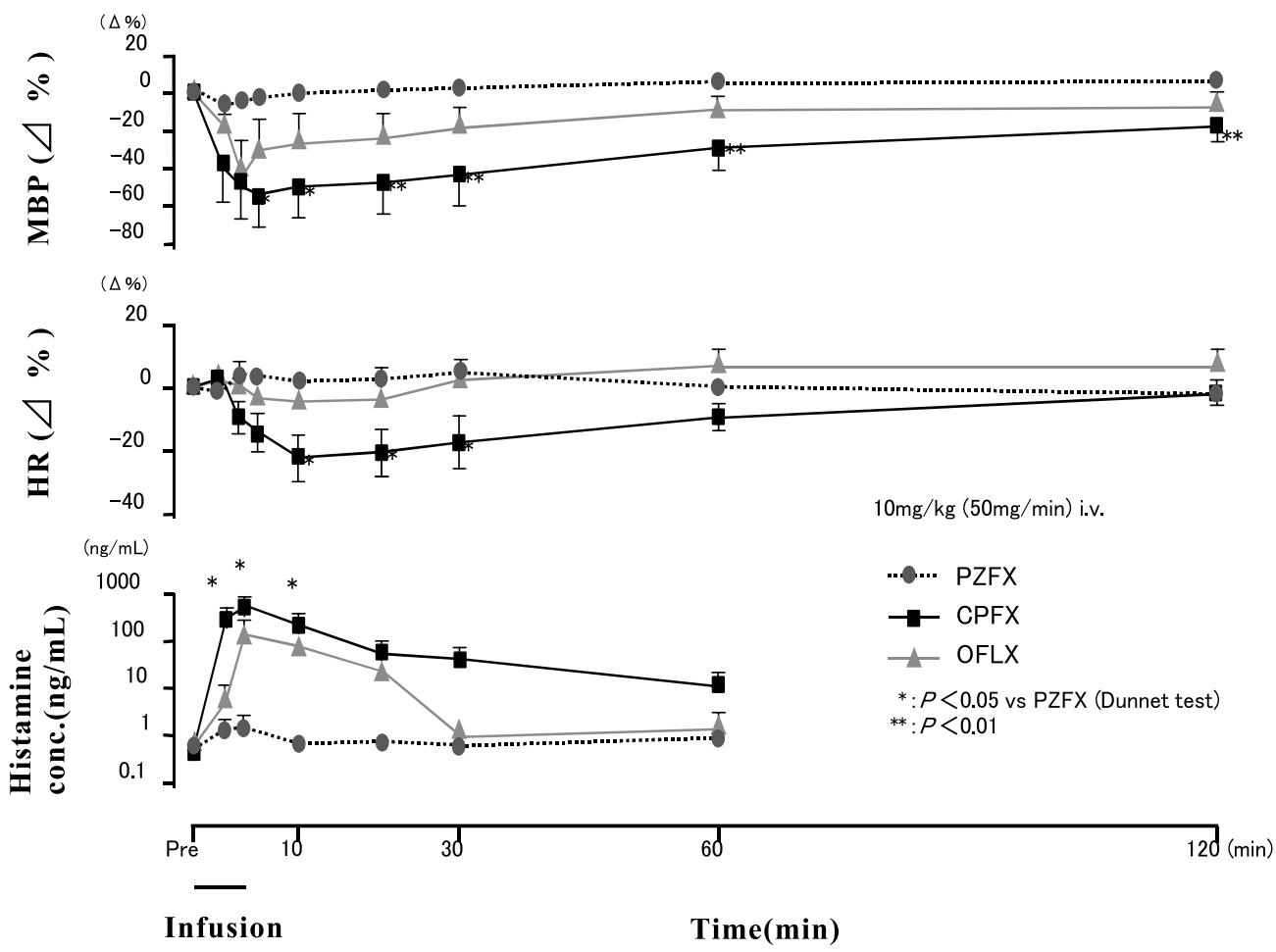

Fig. 6 Effects of pazufloxacin on mean blood pressure (MBP), heart rate (HR), and plasma histamine concentration in anesthetized dogs following intravenous infusion. PZFX: pazufloxacin, CPFX: ciprofloxacin, OFLX: ofloxacin

Table 9 Dye-extravasation in the lateral skin region after intradermal administration of pazufloxacin followed by intravenous injection of $2 \%$ Evans blue in anesthetized dogs $(\mathrm{N}=4)$

\begin{tabular}{|c|c|c|c|c|c|c|c|c|c|c|c|}
\hline \multirow{2}{*}{ Drug } & \multicolumn{10}{|c|}{ Concentration $(\mu \mathrm{g} / \mathrm{mL})$} & \multirow{2}{*}{$\begin{array}{l}\text { Minimum } \\
\text { positive concn. } \\
(\mu \mathrm{g} / \mathrm{mL})\end{array}$} \\
\hline & 2000 & 1000 & 500 & 250 & 125 & 63 & 32 & 16 & 8 & 4 & \\
\hline Pazufloxacin & 2 & 0 & 0 & 0 & 0 & 0 & 0 & 0 & 0 & 0 & 2000 \\
\hline Ofloxacin & 4 & 4 & 4 & 4 & 4 & 4 & 3 & 1 & 0 & 0 & 16 \\
\hline Ciprofloxacin & 4 & 4 & 4 & 4 & 4 & 4 & 4 & 3 & 0 & 0 & 16 \\
\hline
\end{tabular}

る有効率は68.8\% (108/157) であった .また，カルバペ ネム系抗菌薬の前投薬無効例に対し，PZFX の使用による 臨床効果の有効率は $75.0 \%$ (9/12) であり，敗血症 1 例， 腹腔内膿瘍 3 例，骨髄炎 1 例に著効例が見られた。

\section{7. 安全性}

開発時の全体での副作用発現率は 3.4\% (43/1264) で， 既存経口用ニューキノロン系抗菌薬および既存注射用 $\beta$ ラクタム系抗菌薬と同程度であった . 発現した副作用には
本斉特有のものはなく，全て中等度以下の症状で重篤なも のはなかった . また，発現率に用量依存性は認められず， 高齢者においても，特に発現率が高いことはなかった . 臨 床検査值異常の発現率は 15.2\% (180/1187) で, 好酸球の 増多，トランスアミナーゼの上昇などが主で，特異なもの はみられなかった，一方，複杂倠性尿路感染症，細菌性肺炎 および慢性気道感染症を対象とした CAZ との各比較試験 においては, いずれも副作用発現率および臨床検査値異常 発現率に CAZ との差はみられなかった . 


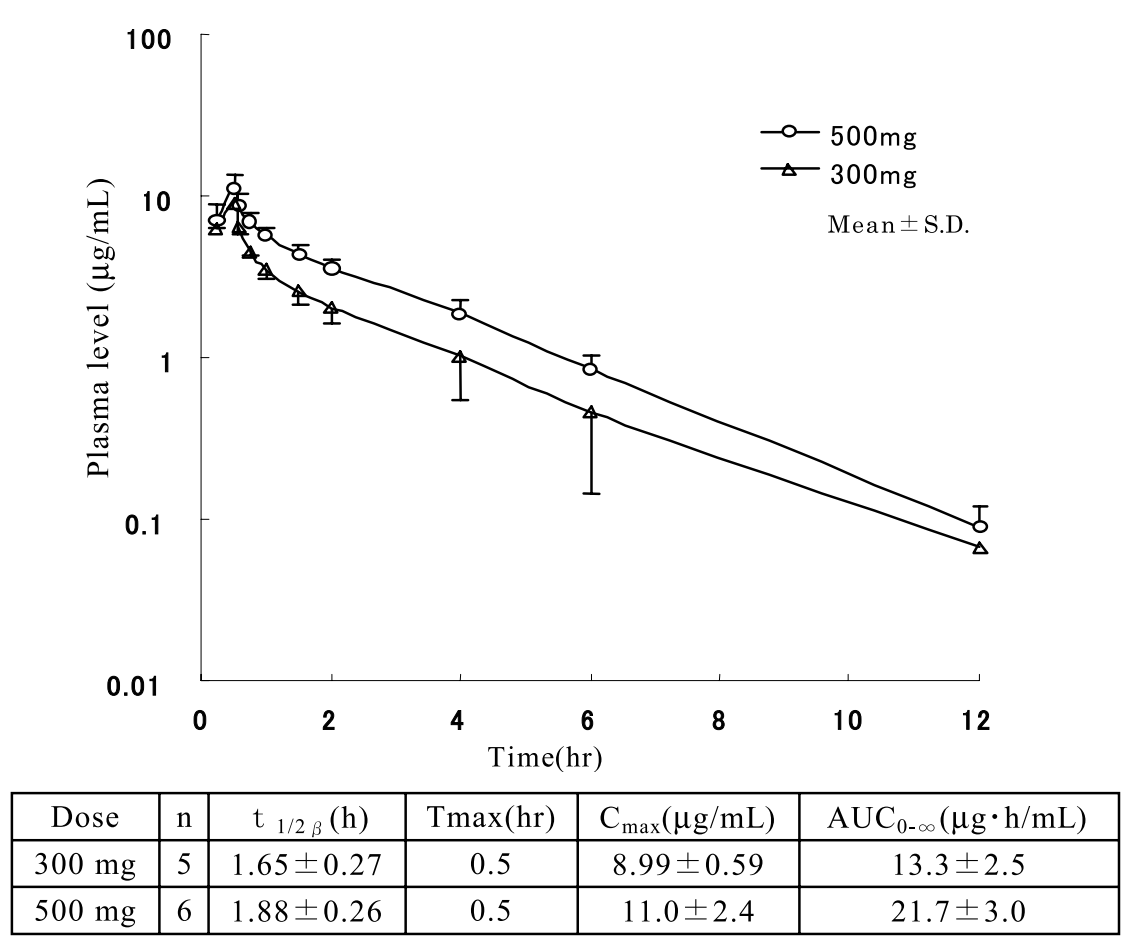

Fig. 7 Plasma levels and pharmacokinetic parameters of pazufloxacin

\section{PZFX の臨床的位置付け}

細菌感染症の治療は優れた抗菌化学療法斉の開発や医療 技術の進歩により大きく進展した。しかし，基礎疾患（慢 性呼吸不全，悪性腫瘍，広範な外傷・熱傷など）や血液疾 患の合併などによる感染防御能の低下などの宿主側の要因， 耐性菌の出現などの病原菌側の要因および気管切開 , カテ 一テル留置などの医療処置に由来する要因などにより重症， 難治化した感染症の増加も指摘されている(10１2) .

これらの感染症を含む注射剂適応の中等症以上の感染症 に対しては, 高い血中濃度が得られ，速やかに良好な病巣 への移行か確保できる注射用抗菌薬が汎用されている(13) . 本邦においては $\beta$-ラクタム系抗菌薬を中心に , arbekacin (ABK) などのアミノグリコシド系および vancomycin ( $\mathrm{VCM})$ などのポリペプチド系抗菌薬などが単独又は併用 して用いられている(14). しかし，これらの抗菌薬では， 治療効果が必ずしも十分でない場合や，また，アナフィラ キシーショックや腎毒性のような重篤な副作用により使用 が制約される場合も見られる(15〜22)．ニューキノロン系 抗菌薬は既存の $\beta$-ラクタム系抗菌薬に比へ，抗菌スペク トルが広く，また，殺菌作用も短時間内に強く発現するこ とから，このような重症・難治性感染症患者にエンペリッ
クな使用が可能と考えられる .

PZFX はこのようなニューキノロン系抗菌薬の特長を有 し，更に従来のニューキノロン系抗菌薬より高い血中濃度 が得られることで, 殺菌性の特長を生体内でより発揮しや すくなっており，広域抗菌薬として注射用 $\beta$-ラクタム系 抗菌薬同樣にエンペリックな使用が可能と考えられる．実 際，これまで集積された臨床試験成績からは，他剂無効例 で良好な゙治療成績が得られたことに加え，既存広域注射用 セフェム系抗菌薬と同等の臨床効果が比較試験において確 認された。しかし，ニューキノロン系抗菌薬の特性で， $\beta$ ラクタム系抗菌薬には見られない濃度依存性の短時間での 強い殺菌性か臨床効果に反映したとの直接的なエビデンス は得られていない，一方，安全性については，開発治験に おける限られた症例数ではあるが, 基礎的検討の成績を反 映し，注射用 $\beta$-ラクタム系抗菌薬と遜色ない成績が得ら れている これらを総合すると, $\mathrm{PZFX}$ は他斉無効の重症・ 難治性感染症に対する治療薬となり得ると期待されるが， これを支持するエビデンスが十分に集積されていない，従 って，現時点では第三世代セフェム系などの広域注射用 $\beta$ ラクタム系抗菌薬か対象とする感染症への使用か望ましい と言える.また，このような使用は $\beta$-ラクタム系に偏っ た使用による耐性菌出現のリスク低下が期待できる． 
Table 10 Clinical efficacy of pazufloxacin by diagnosis

\begin{tabular}{|c|c|c|c|}
\hline Field & Diagnosis & \multicolumn{2}{|c|}{ Efficacy ( \% ) } \\
\hline- & Sepsis & $\mathbf{5} / \mathbf{5}$ & \\
\hline- & Superficial infections & $2 / 2$ & \\
\hline \multirow{6}{*}{ Surgical infections } & Wound infections (trauma, operative wound, burn) & & \\
\hline & Burn wound infections & $8 / 10$ & $(80.0 \%)$ \\
\hline & Other wound infections & $27 / 37$ & $(73.0 \%)$ \\
\hline & (Subtotal) & $35 / 47$ & $(74.5 \%)$ \\
\hline & Osteomyelitis & $1 / 1$ & \\
\hline & Subtotal & $36 / 48$ & $(\mathbf{7 5 . 0 \% )}$ \\
\hline \multirow{13}{*}{$\begin{array}{l}\text { Respiratory tract } \\
\text { infections }\end{array}$} & Chronic bronchitis & $33 / 41$ & $(80.5 \%)$ \\
\hline & Diffuse panbronchiolitis & $13 / 15$ & $(86.7 \%)$ \\
\hline & Bronchiectasis with infection & $42 / 52$ & $(80.8 \%)$ \\
\hline & Secondary infection whith chronic respiratory disease & $44 / 51$ & $(86.3 \%)$ \\
\hline & Pneumonia $\cdot$ Lung suppuration & & \\
\hline & Pneumonia & $256 / 295$ & $(86.8 \%)$ \\
\hline & Lung suppuration & $9 / 18$ & $(50.0 \%)$ \\
\hline & (Subtotal) & $265 / 313$ & $(84.7 \%)$ \\
\hline & Pyothorax & $3 / 6$ & $(50.0 \%)$ \\
\hline & Lung abscess & $1 / 1$ & \\
\hline & Pleurisy & $1 / 2$ & \\
\hline & Acute lower respiratory tract infections & $1 / 2$ & \\
\hline & Subtotal & $403 / 483$ & $(83.4 \%)$ \\
\hline \multirow{4}{*}{ Urinary tract infections } & Complicated pyelonephritis & $141 / 167$ & $(84.4 \%)$ \\
\hline & Complicated cystitis & $193 / 224$ & $(86.2 \%)$ \\
\hline & Prostatitis & $7 / 7$ & $(100 \%)$ \\
\hline & Subtotal & $341 / 398$ & $(85.7 \%)$ \\
\hline \multirow{6}{*}{$\begin{array}{l}\text { Liver and biliary tract } \\
\text { infections }\end{array}$} & Cholecystitis, Cholangitis & & \\
\hline & Cholecystitis & $11 / 13$ & $(84.6 \%)$ \\
\hline & Cholangitis & $15 / 16$ & $(93.8 \%)$ \\
\hline & (Subtotal) & $26 / 29$ & $(89.7 \%)$ \\
\hline & Liver abscess & $3 / 4$ & \\
\hline & Subtotal & $29 / 33$ & $(87.9 \%)$ \\
\hline \multirow{3}{*}{ Intra-abdominal infections } & Peritonitis & $21 / 25$ & $(84.0 \%)$ \\
\hline & Intraabdominal abscess & $12 / 19$ & $(63.2 \%)$ \\
\hline & Subtotal & $33 / 44$ & $(75.0 \%)$ \\
\hline- & Pelvic peritonitis & $13 / 15$ & $(86.7 \%)$ \\
\hline \multirow{3}{*}{$\begin{array}{l}\text { Obstetric and gynecology } \\
\text { Infections }\end{array}$} & Adnexitis & $20 / 21$ & $(95.2 \%)$ \\
\hline & Parametritis & $8 / 10$ & $(80.0 \%)$ \\
\hline & Subtotal & $28 / 31$ & $(90.3 \%)$ \\
\hline & Total & 890 / 1060 & $(84.0 \%)$ \\
\hline
\end{tabular}

以上, PZFX は, 臨床試験成績より既存の注射用抗菌薬 と同樣, 安全に使用できる注射用ニューキノロン系抗菌薬
であると判断され，また，広域の適応症を有することから， ニューキノロン系の注射用広域抗菌薬として新たな臨床的 
Table 11 Bacteriological response of pazufloxacin by causative organisms

\begin{tabular}{|c|c|c|c|}
\hline \multicolumn{2}{|c|}{ Causative organisms } & \multicolumn{2}{|c|}{ Elimination rate ${ }^{*}(\%)$} \\
\hline \multirow{20}{*}{$\begin{array}{l}\text { Monomicrobial } \\
\text { infection }\end{array}$} & Staphylococcus spp. & $41 / 49$ & $(83.7)$ \\
\hline & MRSA & $7 / 12$ & (58.3) \\
\hline & Streptococcus spp. & $6 / 8$ & $(75.0)$ \\
\hline & S. pneumoniae & $53 / 74$ & $(71.6)$ \\
\hline & Enterococcus spp. & $30 / 40$ & $(75.0)$ \\
\hline & M. catarrhalis & $12 / 12$ & $(100)$ \\
\hline & E. coli & $63 / 63$ & $(100)$ \\
\hline & Citrobacter spp. & $8 / 10$ & $(80.0)$ \\
\hline & Klebsiella spp. & $24 / 26$ & $(92.3)$ \\
\hline & Enterobacter spp. & $11 / 11$ & $(100)$ \\
\hline & Serratia spp. & $11 / 11$ & $(100)$ \\
\hline & Proteus spp. & $5 / 5$ & \\
\hline & Providencia spp. & $6 / 6$ & $(100)$ \\
\hline & H. influenzae & $42 / 43$ & $(97.7)$ \\
\hline & Pseudomonas spp. & $1 / 1$ & \\
\hline & $P$. aeruginosa & $31 / 64$ & $(48.4)$ \\
\hline & Acinetobacter spp. & $2 / 3$ & \\
\hline & Bacteroides spp. & $3 / 5$ & \\
\hline & Prevotella spp. & $1 / 1$ & \\
\hline & Other & $13 / 13$ & $(100)$ \\
\hline & Subtotal & $370 / 457$ & $(81.0)$ \\
\hline \multirow{3}{*}{$\begin{array}{l}\text { Polymicrobial } \\
\text { infection }\end{array}$} & Two pathogens & $129 / 192$ & $(67.2)$ \\
\hline & Three or more pathogens & 63 / 95 & $(66.3)$ \\
\hline & Subtotal & $192 / 287$ & $(66.9)$ \\
\hline & Total & $562 / 744$ & $(75.5)$ \\
\hline
\end{tabular}

* (elimination + replaced $) /($ No. of patients (excluding unknown data $))$

位置付けが期待される .

現在の臨床的位置付けとしては, 今後, 臨床現場での安 全性における実績を積み重ねながら, ペニシリン系あるい は第一, 第二世代セフェム系が無効あるいは適切でないと 予想され，第三世代セフェム系あるいはカルバペネム系が 対象となる感染症への使用が推奨され，また，第三世代セ フェム系あるいはカルバペネム系と同等で，互いに替わり 得る薬剂と言えるであろう．

\section{9. おわりに}

PZFX は国産初の注射用ニューキノロン系抗菌薬であり， 既存の経口用ニューキノロン系抗菌薬より高い血中濃度を 得られることで優れた臨床効果が期待され，同時に安全に 使用できることが注射用セフェム系抗菌薬 CAZ との比較 試験を含めた臨床試験段階で認められた．また，既存注射
薬の効果不十分な症例に対する本斉の有効性も示されてい る . 今後 , 臨床現場において更に安全性および有効性の実 績が集積されることで, 細菌感染症に対する新たな選択肢 としての本斉の位置付けが明確になり，更には耐性菌出現 抑制の一助となることを期待するものである .

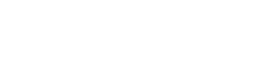

1) Davis RL, Kalman D, Marchbanks CR. Intravenous ciprofloxacin: a position statement by the society of infectious diseases pharmacists. Ann Pharmacother. 1993;27:362-364.

2) 引間康夫, 香月正憲, 見永武芳, 半田 光, 中塚一伸. ニューキノロン薬の静注適用 . In: 上田 泰 他編 . キノロン薬.ライフ・サイエンス; 1991. p.297-309.

3) Leroy O, Beuscart C, Chidiac C, Beaucaire G, Sivery B, Mouton Y. First Experience of Ofloxacin IV: 273 Patients in a French Multicentric Study, 
Table 12 Clinical efficacy of pazufloxacin in non-responders to prior treatment with other antimicrobial agents

\begin{tabular}{|c|c|c|c|c|c|c|c|c|}
\hline \multirow{2}{*}{\multicolumn{2}{|c|}{ Prior treatment agents }} & \multirow{3}{*}{$\begin{array}{c}\begin{array}{l}\text { No.of } \\
\text { cases }\end{array} \\
9\end{array}$} & \multicolumn{4}{|c|}{ Clinical efficacy } & \multirow{2}{*}{\multicolumn{2}{|c|}{ Efficacy* ( \% ) }} \\
\hline & & & \multirow{2}{*}{$\frac{\text { Excellent }}{3}$} & \multirow{2}{*}{$\frac{\text { Good }}{5}$} & \multirow[t]{2}{*}{ Fair } & \multirow{2}{*}{$\begin{array}{c}\text { Poor } \\
1\end{array}$} & & \\
\hline Penicillins & IV & & & & & & $8 / 9$ & (88.9) \\
\hline \multirow{2}{*}{ Cephems } & $\mathrm{PO}$ & 27 & 9 & 12 & & 6 & $21 / 27$ & $(77.8)$ \\
\hline & IV & 15 & 4 & 5 & 2 & 4 & $9 / 15$ & $(60.0)$ \\
\hline Carbapenems & IV & 12 & 5 & 4 & 1 & 2 & $9 / 12$ & $(75.0)$ \\
\hline Penems & $\mathrm{PO}$ & & & & & & & \\
\hline \multirow{2}{*}{ Other $\beta$-lactams } & $\mathrm{PO}$ & 1 & & 1 & & & $1 / 1$ & \\
\hline & IV & 11 & 1 & 6 & 2 & 2 & $7 / 11$ & $(63.6)$ \\
\hline \multirow{2}{*}{$\beta$-lactams } & $\mathrm{PO}$ & 28 & 9 & 13 & & 6 & $22 / 28$ & $(78.6)$ \\
\hline & IV & 47 & 13 & 20 & 5 & 9 & $33 / 47$ & $(70.2)$ \\
\hline Quinolones & $\mathrm{PO}$ & 28 & 5 & 11 & 6 & 6 & $16 / 28$ & (57.1) \\
\hline $\begin{array}{l}\text { Other synthetic } \\
\text { antimicrobial agents }\end{array}$ & $\mathrm{PO}$ & 2 & & 2 & & & $2 / 2$ & \\
\hline \multirow{2}{*}{$\begin{array}{l}\text { Macrolides } \\
\text { lincomycines }\end{array}$} & $\mathrm{PO}$ & 10 & & 8 & 1 & 1 & $8 / 10$ & $(80.0)$ \\
\hline & IV & 1 & & & 1 & & $0 / 1$ & \\
\hline \multirow{2}{*}{ Other } & $\mathrm{PO}$ & 1 & & 1 & & & $1 / 1$ & \\
\hline & IV & 8 & 3 & 2 & 1 & 2 & $5 / 8$ & $(62.5)$ \\
\hline \multirow{2}{*}{ Subtotal } & $\mathrm{PO}$ & 69 & 14 & 35 & 7 & 13 & 49 / 69 & (71.0) \\
\hline & IV & 56 & 16 & 22 & 7 & 11 & $38 / 56$ & $(67.9)$ \\
\hline \multicolumn{2}{|c|}{ Two or more antimicrobial agents } & 32 & 5 & 16 & 7 & 4 & $21 / 32$ & $(65.6)$ \\
\hline \multicolumn{2}{|c|}{ Total } & 157 & 35 & 73 & 21 & 28 & $108 / 157$ & $(68.8)$ \\
\hline
\end{tabular}

*(Excellent + Good $) /$ No.of cases

Program and Abstracts of the Twenty-Eighth Interscience Conference on Antimicrobial Agents and Chemotherapy (California), Abs.383, 1988

4) 小林宏行, 河合 伸, 押谷浩, 他 . Ciprofloxacin 注射薬の後期第 II 相臨床試験 - 重症および難治性感染 症における臨床的検討 - . 日化療会誌 . 1997;45(10)： 846-869.

5) Arcieri GM, Becker N, Esposito B, et al. Safety of intravenous ciprofloxacin. Am J Med. 1989;87 Suppl 5A:92S-97S.

6) 小林宏行, 原 耕平, 熊澤淨一, 酒井克治. Ciprofloxacin 注射薬の後期第 II 相臨床試験 . 日化療会誌. 1997; 45(10):833-845.

7) 金沢 裕, 倉又利夫.寒天平板拡散法による Nalidixic acid の体液中濃度測定法ならびに感受性測定法 .Chemotherapy . 1964;12(3):176-179.

8) 平井嗣郎, 田中啓一, 牧野伸治, 成田弘和 .ピリドン カルボン酸系抗菌剂及び非ステロイド性抗炎症剂の薬 物相互作用 : マウスでの経口及び脳内投与による痙攣 誘発。薬誌. 1989;109(2):119-126.

9) 嶋田甚五郎, 堀誠治. キノロン剂の GABA 受容体 結合に及ぼす影響. In: 三橋 進編，ニューキノロン 一あすの抗囷剂をめざして. 学会出版センター; 1991. p. 198.

10) 今野 淳, 渡辺 彰. 特集 - 難治性呼吸器感染症の治 療 - 総論 . 化療の領域 . 1988;4(6):1065-1070.
11）国井乙彦 : 特集 - 難治性感染症と日和見感染 - Compromised host と感染症. 臨床と研究. 1986;63(7): 2124-2131.

12）厚生省薬務局安全課. 各抗生物質に対する耐性率，抗 生物質感受性状況調査報告. In: (財) 医療情報シス テム開発センター編. 1993 (上), 1996 (上).

13）松本文夫, 森田雅之, 若林康弘, 佐藤康信 . 注射用抗 菌剂の使い方 .月刊薬事 . 1990;32(12):2555-2558.

14) 古川恵一 . 各種の主要感染症の起因菌と初期治療 $(\mathrm{em}-$ piric therapy). Medicina . 1999;36(1):18-25.

15) 谷本普一，抗菌斉の副作用 . 臨床成人病 . 1987;17(増 刊号):46-51.

16) 後藤俊弘 . アミノグリコシド (AGs) . 化学療法の領 域 . 1996;12(S-1):64-75.

17) 塩酸バンコマイシン点滴静注用 $0.5 \mathrm{~g}$ 添付文書 (塩野 義)

18) 斈 康雄, 大谷津 功，馬場ますみ，他．他剂無効例 に対する imipenem/cilastatin sodium の臨床的検討 . Chemotherapy . 1990;38(4):363-370.

19) 第 42 回日本化学療法学会 新薬シンポジウム E1077 (平成 6 年 6 月, 福岡)

20) 第 39 回日本化学療法学会総会 新薬シンポジウム I Meropenem (SM-7338) (平成 3 年 6 月, 東京)

21) 第 41 回日本化学療法学会西日本支部総会 新薬シン ポジウム L-627 (平成 5 年 12 月, 神戶)

22) 第 31 回日本化学療法学会西日本支部総会 新薬シン 

種薬斉の抗菌活性 . 富山化学工業株式会社社内報

\begin{abstract}
Pharmacological properties and expected clinical role of an injectable new quinolone antibiotic, pazufloxacin mesilate. Shinzaburo MINAMI ${ }^{1)}$, Rikizou HATTORI ${ }^{2)}$ and Akira MATSUDA ${ }^{3)}\left({ }^{1)}\right.$ Research Laboratories, Toyama Chemical Co. Ltd., 2-4-1, Shimookui, Toyama 930-8508, Japan, ${ }^{2)}$ Clinical Research Department, Toyama Chemical Co. Ltd., 3-2-5, Nishisinjuku, Shinjyuku-ku, Tokyo 160-0023, Japan and ${ }^{3)}$ Drug Regulatory Affairs Department, Toyama Chemical Co. Ltd., 3-2-5, Nishisinjuku, Shinjyuku-ku, Tokyo 160-0023, Japan). Folia Pharmacol. Jpn. (Nippon Yakurigaku Zasshi) 122, 161 178 (2003)

Pazufloxacin mesilate (PZFX: Pasil INJECTION, Pazucross INJECTION) is a novel injectable quinolone antibiotic that was discovered by Toyama Chemical Co., Ltd. and codeveloped by Toyama Chemical Co. Ltd. and Mitsubishi Pharma Corporation. Laboratory studies indicated that PZFX reached high plasma levels quickly after intravenous administration, and it exhibited weak convulsion inducing activity, low local irritant effect, and less hypotensive activity, all of which are generally recognized as side effects associated with other injectable quinolones. PZFX has potent antibacterial and bactericidal activities against cephalosporin-, carbapenem-, and aminoglycoside-resistant strains. These favorable antibacterial and bactericidal activities gave PZFX superior therapeutic effects, compared to injectable cephalosporin antibiotics, on experimental animal infection models caused by those resistant strains. Clinical studies also revealed PZFX was as safe and effective as the injectable cephalosporin, ceftazidime, against various moderate to severe infections. Furthermore, PZFX showed good clinical effects on the infections resistant to chemotherapy by the other antimicrobial agents. These results indicate that PZFX is a viable choice for various bacterial infections. In this review, results of laboratory and clinical studies are summarized and the clinical role of PZFX among the injectable antimicrobials is discussed.
\end{abstract}

Keywords: pazufloxacin mesilate; injectable quinolone; resistance; DNA gyrase; topoisomerase

著者プロフィール

南 新三郎（みなみしんざぶろう）

富山化学工業株式会社 綜合研究所 研究管理部長 医学博士

$\diamond 1977$ 年 3 月金沢大学大学院薬学研究科修士課程終了, 同年 4 月富山化学工業株式会社 (綜合研究所) 入社, 同年 8 月から 2 年間群馬大学医学部微生物学教室研究生 . ' 86 年群馬大学より医学博士号を取得 .' 94 年上田記念感染症.

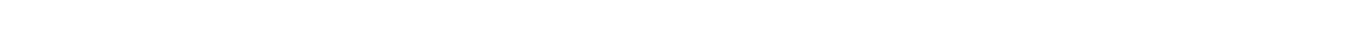

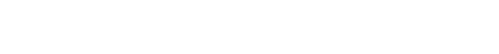

富山化学工業株式会社 臨床開発部 副部長

$\diamond 1978$ 年 3 月岐阜大学大学院工学研究科修士過程終了，同年 4 月富山化学工業株式会社（綜 合研究所) 入社，合成部門配属．’85 年 3 月，臨床開発部入転任 . 抗炎症，抗癌，抗感染症領 域のモニター業務を経て, 抗菌薬の開発担当. 趣味 : ドライブ, ゴルフ .

松田＼cjkstart朗（まつだ あきら）

富山化学工業株式会社 薬事室長

$\diamond 1982$ 年 3 月立教大学理学部化学科卒業, 同年 4 月富山化学工業株式会入社, 主に学術情報部で消化器系, 循環器 系, 中枢神経系用薬および抗菌薬の製品概要作成業務等を経て, ’98 年より薬事室勤務, 承認申請資料作成および申 請業務等を担当.

$\diamond$ 趣味 : 映画鑑賞, 自動車, 園芸, 愛犬 (ミニチュア・シュナウザー)
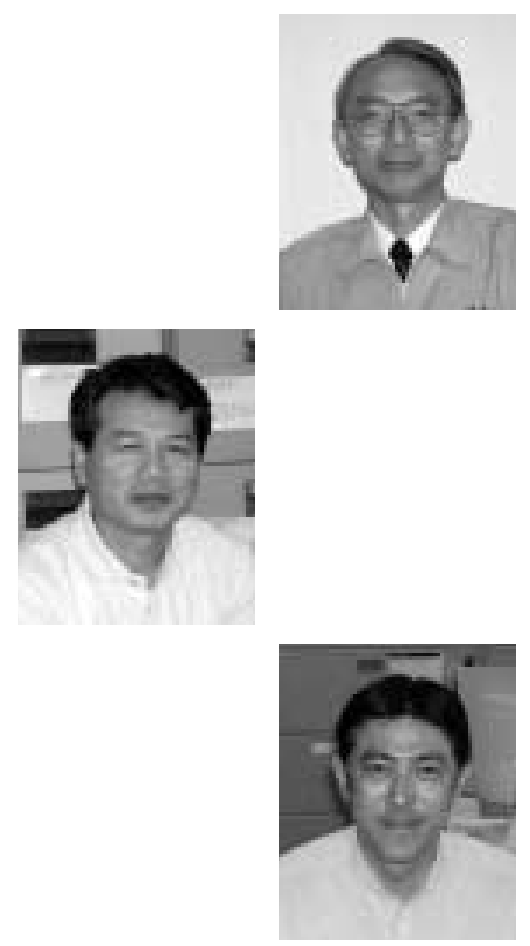